\title{
Translation as Interpretation: Translating Galen's Polysemous Term Physis into Arabic
}

\author{
Elvira Wakelnig*
}

In the ninth century almost the entire corpus of the Greek physician Galen was translated into Arabic, mainly by Ḥunayn ibn Ishāa and his circle. A key concept of Galen’s thought is nature (physis) and the physician uses it in many ways and with different meanings. His late antique commentators show great awareness of the polysemy of the term physis, and the same applies to his Arabic translators. So the question arises of how Hunayn and his circle dealt with this polysemous term - did they choose a similarly polysemous Arabic term to keep the ambiguity of the original or did they render the text more precise by employing different terms? In the latter case, they would have provided not only a translation but also a concise account of how they understood nature in a given translated passage and/or how they wanted their audience to understand it. The article studies one particular case, the translation of the term physis within the Arabic translation of On Diseases and Symptoms done by either Hunayn or his nephew Ḥubayš. The exhaustive comparison between the Greek passages and their corresponding Arabic translations documented in the appendix shows that the translator mainly translated physis by two different terms of the same root, i.e. tabi' $a$, which is mostly used in phrases conveying an activity, and tab; which is mainly employed in an adverbial sense. Particularly interesting are cases in which physis is simply not translated, as in some of them Galen may speak about demiurgic Nature, a principle that he often equates to the divine Demiurge, especially in his On the Usefulness of the Parts. These findings also allow for some tentative suggestions regarding the translation's intended audience.

Keywords: Galen; Graeco-Arabic translations; Hunayn ibn Ishāq; Ḥubayš ibn al-Ḥasan; nature; On Diseases and Symptoms; polysemy

How does a translator deal with polysemous words? Does he choose one term to translate such a polysemous word, consistently sticking to the chosen equivalent and thus rendering the polysemy as well as the ambiguity of the original? Or does he use his translation as an opportunity to make the text less ambiguous by interpreting the polysemous term each time it occurs and by translating it differently according to how he understands the given polysemous word at every particular occurrence? In the latter case, the translator interprets the text he translates and furnishes us not only with a translation but also with his understanding * Correspondence details: Elvira Wakelnig, Department of Near Eastern Studies, University of Vienna, Spitalgasse
2, Hof 4, 1090 Vienna, Austria; email: elvira.wakelnig@univie.ac.at. 
of it. This, in turn, provides an interesting insight into how a text was read and understood at the time of its translation in the milieu of the translator in question. It may further indicate how the translator wanted to present the translated text to his audience and which understanding he hoped to convey to his readers. As a case in point, I want to pose these questions with regard to the rendering of the polysemous term "nature " (physis) $)^{1}$ in the ninth-century Graeco-Arabic translation of Galen's On Diseases and Symptoms. There are various reasons for having chosen this text. The Galenic œuvre which was translated into Arabic almost in its entirety in the ninth century played an important role in the constitution of scientific enquiry in the Arabic-Islamic world, a role which is still understudied. For whereas the Arabic translations of the Aristotelian corpus, which was likewise nearly completely translated into Arabic, are edited and studied, the Galenic translations still remain, for the most part, unedited and unstudied, which also applies to On Diseases and Symptoms. Yet, the corpora of these two great Ancient Greek scientists were translated at the same time, sometimes by the same people, and are thus equally important for our reconstruction of the development of scientific terminology in Arabic. ${ }^{2}$ Furthermore, the concept of nature is a highly disputed one in the Arabic-Islamic tradition and some groups of Muslim scholars reject it due to its assumed limitation of God's omnipotence. Most prominently refuted is the idea that living beings act and react according to their inborn natures, for if they did, they would no longer be directly dependent on the divine decree. ${ }^{3}$ The understanding of nature as an intelligent agent, as an almost personified demiurgic Nature is also denied, ${ }^{4}$ although less vehemently, as the idea did not seem to have become sufficiently widespread in Arabic, as will be shown below. On Diseases and Symptoms contains passages in which the term "nature is used in these two meanings as well as passages in which it is applied in several others. Thus the treatise provides an excellent case study for the translation of this polysemous term by one single translator at one particular time in his life and, probably, for one particular patron who commissioned the translation. A good understanding of each individual translation is indispensable for making broader comparisons between various translators and their translation methods possible.

A particularly interesting aspect of the so-called "Graeco-Arabic translation movement" during which the Aristotelian and the Galenic œuvres were translated is that almost all Arabic translators were Christians and thus in a somewhat exposed position within the Muslim society. ${ }^{5}$ These Christians translated into Arabic mainly for Muslim patrons, whereas some of

1 I have opted for using quotation marks to indicate terms in English, but for omitting them when indicating Greek and Arabic terms in transliteration.

2 The list of the four meanings of nature according to Hippocrates which occurs in a summary or Ğawämi of Galen's Book to Glaucon (Kitäb Ğälīnūs ilä Gulüqun) and is cited below appears almost verbatim in the Epistle on the

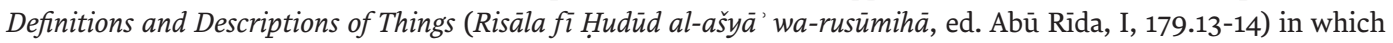
the so-called first philosopher of the Arabs, al-Kindi (d. after 866) defines philosophical terms.

3 See, for example, Bernand, Critique.

4 The physician and philosopher Abū Bakr al-Rāzī (d. 925), for instance, argues against it, see Genequand, Quelques aspects, 123-125.

5 On the translation movement, see Gutas, Greek Thought; and Saliba, Islamic Science, esp. 60-64 where he advances a very interesting hypothesis about the position of the Christian translators in the developing Muslim society. 
them also translated into Syriac for their co-religionists. This has in particular been shown for Hiunayn ibn Ishāa and his circle, ${ }^{6}$ from which the Arabic translation of On Diseases and Symptoms stems. Hunayn's translation techniques have already been studied for more than a century, yet his approach to polysemous terms has, as far as I am aware, never been dealt with in any detail. ${ }^{7}$

\section{The Polysemous Term "Nature" in the Galenic Greek and Arabic Traditions}

The polysemy of, in particular, scientific terms was already discussed by Aristotle in the fourth century BC. More than once, he turns the attention of his readers to the fact that a term discussed may be applied "in many ways" (pollachōs). Half a millennium later, Galen uses the very same expression pollachōs to refer to the manner in which "nature " physis) is said. ${ }^{8}$ Unfortunately, he does not list these many ways of saying "nature", and the account which he claims to have given of the signification (semainomenon) of "nature" in the fifth book of his Medical Names seems lost. ${ }^{9}$ However, the late antique commentators of both Aristotle and Galen develop the habit of compiling lists of definitions and divisions in which the various meanings of philosophical and scientific terms are gathered. ${ }^{10}$ Galenic commentators supply us with several diverging lists of the meanings of "nature«. Given the crucial importance which the term "nature" has for understanding Galen's medical thought, it comes as no surprise that such lists are found at the very beginning of the late antique Galenic curriculum, i.e. in the commenting and compiling literature of On the Sects with which the medical teaching was bound to begin. ${ }^{11}$ Due to the fragmentary state of the late antique Greek texts on On the Sects, there is only one list of the meanings of "nature " preserved in Greek, namely in the Tabulae Vindobonenses. It reads: ${ }^{12}$

6 See Watt, Why.

7 Pioneering work was done by Bergsträsser, Meyerhof, Schacht and Strohmaier. For more recent studies and further references, see Vagelpohl, User-friendly Galen; Cooper, Ḥunayn ibn Isḥāq’s Galen translations; and Overwien, Art of the translator.

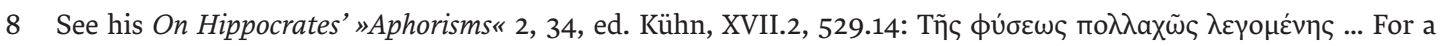
discussion of the passage, see Jouanna, Notion, 230-233.

Porphyry, who was Galen's contemporary and a commentator of Aristotle, uses the same expression in his commentary to the Categories in question-and-answer form and employs the same principle, i.e. citing different meanings of one and the same term, in the Isagoge, his introduction to the Categories.

9 In his On Hippocrates' "Nature of Man", 1, Prooemium, ed. Mewaldt, 6.9-11, Galen claims to have provided an account of the signification of »nature«. His Medical Names are lost in Greek and only the first book seems to have been translated into Arabic. See Jouanna, Notion, 229; and Garofalo, Nature, 753. For the edition of the surviving Arabic text of the first book by Meyerhof and Schacht, see Galen, On Medical Names.

10 A particularly late product of this development can be found in an anonymous commentary on Porphyry's Isagoge in which a section on definitions and divisions is placed between the introductory material to philosophy and to the Isagoge and the beginning of the commentary proper. See Moraux, Unedierter Kurzkommentar, 76-81 and 9698. For the lists of the meanings of "nature in Hippocrates and Galen, see Jouanna, Notion; and Garofalo, Nature.

11 See the most recent presentation of the Galenic curriculum with further references in Overwien, Medizinische Lehrwerke, 10-18; and on On the Sects in the curriculum, see ibid., 30-34.

12 On the various extant fragments on On the Sects, see Overwien, Medizinische Lehrwerke, 26-30. The Greek text

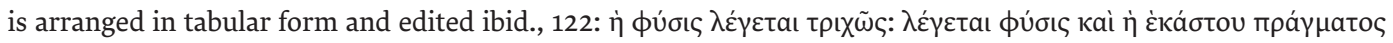

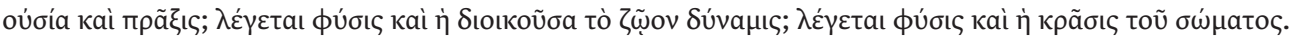
If not otherwise stated, all English translations are mine. 
"Nature« is said in three ways: nature is called the substance (or essence) and praxis ${ }^{13}$ of every thing; nature is called the power governing the animal; nature is called the mixture of the body.

Other lists also going back to the late antique medical teaching tradition survive in Latin ${ }^{14}$ and in Arabic and display a considerable range of variation. Some can be found in the socalled Summaries of the Alexandrians (Ğawāmi al-Iskandarāniyinn), i.e. summaries of Galenic treatises, which are almost exclusively preserved in Arabic but clearly go back to the Greek Alexandrian tradition. In the summary or Ğawami of On the Sects, the list of the meanings of "nature" is similar to the Greek of the Tabulae Vindobonenses, yet with some remarkable differences: $:^{15}$

For this term, I mean "natural-disposition « $(t a b)$ or "nature« $\left(\operatorname{tabi}^{\prime} a\right)$ is employed in three ways: One of them is the substance of every thing and its existence, the second is the power governing the animal's body, and the third is the mixture of the body and its habit.

To begin with, two Arabic terms of the same root $(t-b-)$ are given as equivalent to the Greek term physis, namely $t a b^{16}$ which I translate as natural-disposition, and tabi ${ }^{-} a$. In a number of other texts which we shall consider in what follows, tabi'a remains the only term in similar passages, whereas tab is used to indicate a particular meaning of tabi $a$, namely the mixture or disposition of a body. T⿱ab ' thus becomes restricted to a particular section of the semantic field of tabi ${ }^{\prime} a$. The unusually wide range of $t a b^{\prime}$ here may be seen as evidence that this Arabic text was translated early on, in a period when the technical terminology was still being developed. ${ }^{17}$

Regarding the first meaning, the Arabic text mentions substance and existence. If the term »existence" (wuğùd) is not understood along the lines of essence and thus interpreted as part of a hendiadys "substance and existence«, it may be explained as a rendering of hyparxis assuming that the Arabic author of the Ğawämi' read this in his Greek model. For in the Late Greek Patristic tradition ousia and physis are not only said to mean the same thing,

13 I leave the Greek term untranslated for the moment as I will refer to it shortly when discussing the Arabic version. Overwien (ibid., 123) translates praxis as "Verfassung".

14 See the Latin version of Johannes Alexandrinus' commentary On the Sects, which was probably translated from the Greek, ed. Pritchet, vii and 35-36; and the Lectures On the Sects of Agnellus, who probably taught in Latin, Lectures, xii-xiii and 62-63.

15 On the Alexandrian summaries of the sixteen books of the Galenic curriculum, see Sezgin, GAS III, 140-150; on the summaries of other Galenic treatises, see Savage-Smith, Galen's lost ophthalmology, 128-131; on the summary of On the Sects in particular, see Pormann, Alexandrian Summary; and Overwien, Medizinische Lehrwerke, 47-67. The Arabic text has recently been edited with an English translation in Walbridge, Alexandrian Epitomes 1, 7-48. For the Arabic of the cited passage, see ibid., 17:

وذلك أنّ هذا الاسمم ، أعني طبعاً أو طبيعةً تتصرّف على ثلثة وجوه ، أحدها جوهر كلّ واحدٍ من الأشياء ووجوده ، الثاني القوّة المدبّرة لبدن الحيوان ، والثالث مزاج

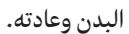

16 I use two different English terms to distinguish the two Arabic ones. To indicate that my translation "natural-disposition« renders a single Arabic word ( $t a b)$, I write it with a hyphen.

17 For the specific use of tab in contrast to țabía, see below. 
but both are said to indicate hyparxis, i.e. existence. ${ }^{18} \mathrm{~A}$ similar identification may also have occurred in the medical milieu, either due to Christian influence or independently, based on philosophical considerations. If this were the case, even the Greek praxis in the Tabulae Vindobonenses could be a mistransmission for hyparxis. ${ }^{19}$ The third meaning is rendered more precise by the addition of the concept habit, which is probably meant to exclude the application of the term "nature " to a body whose mixture is out of its normal condition. ${ }^{20}$ Alternatively, it may imply the ethical concept of an acquired second nature as expressed in the Arabic epitome of Galen's On Moral Character. ${ }^{21}$

Different meanings of "nature " are also presented in the commentary to On the Sects by the physician, philosopher and Christian theologian Ibn al-Tayyib (d. 1043), who commented on a great number of Aristotelian and Galenic treatises making use of late antique commentaries: ${ }^{22}$

According to Hippocrates' teaching, "nature $\left(\operatorname{tabi}^{\prime} a\right)$ is said in four ways:

in the way of the mixture of every body part - that is to say that some mixtures are good in summer such as (those of) scorpions and serpents and bad in winter; and that is to say that the mixtures of these are by natural-disposition (bi-l-tab) cold and some others are opposite, such as those over whose mixtures heat prevails;

in the way of the constitution of every body part - that is to say that the chest of some people is by natural-disposition narrow, and about these Hippocrates says that phthisis quickly comes to them and stays in them due to their minimal ability to inhale air in the degree of hotness, so he links the original hotness to the mixture of their body parts; in the way of the powers governing the animal's body - they are those through which the digestion of food is completed, just as Hippocrates says that nature is sufficient in all; and in the way of the psychic activities like courage in the lion and fear in the fox as Hippocrates says that the nature of every body part is without instruction - he means that it does what it does without teaching.

18 Cf. Theodore of Raïthu, Praeparatio, ed. Diekamp, 202.18-21; Doctrina Patrum, ed. Diekamp, 40.17-20; John of Damascus, Institutio Elementaris, ed. Kotter, 94.26-27, 107.7. I would like to thank Christophe Erismann for having drawn my attention to the Late Patristic tradition in general and in particular to the passage by Theodore, who was the abbot of Raithu in the Sinai peninsula at the end of the sixth and the beginning of the seventh centuries.

19 Unlike Overwien (Medizinische Lehrwerke, 172, n. 39), I do not think that wuğùd can be taken as a translation of praxis. If one wants to assume that the Arabic author of the Gawami 'worked on a Greek model very similar to the Tabulae Vindobonenses, one may imagine that he, who was most probably a Christian as the great majority of the Graeco-Arabic translators were, may have interpreted the Greek praxis according to his religious background.

20 Whether the mention of habit can in any way be linked to the surprising occurrence of »usual power « (habitudinalis virtus) in the Latin version of Johannes' commentary on Hippocrates' Epidemics, ed. Pritchet, 212.1-2 remains to be ascertained.

21 See Kraus, Kitāb al-ahlāq, 49.ult.:

$$
\text { وقد قلنا إنّ العادة طبيعة ثانية }
$$

I would like to thank Almuth Lahmann who has brought this notion of a second nature to my attention.

22 In the only manuscript of the commentary known to survive, Manissa, MS 1772, 13b17-14a11, the Arabic text reads as follows:

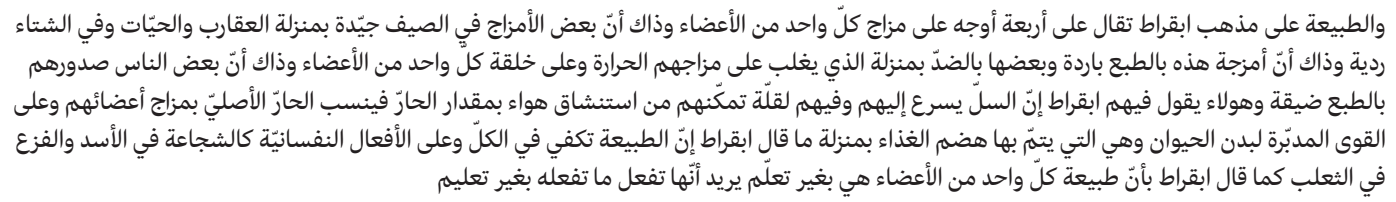


Ibn al-Tayyib's list shows closer similarities to the Latin versions of the commentaries to $O n$ the Sects than to the Tabulae Vindobonenses, but he is, in particular, close to the meanings of "nature" listed at the beginning of the commentaries to Galen's Therapeutics to Glaucon, the fourth treatise in the late antique Galenic curriculum. ${ }^{23}$ In the summary or Ğawāmi ' of $\mathrm{Ga}$ len's Book to Glaucon (Kitäb Ğâlīnūs ilä Gulüqun), a similar list occurs at the very beginning. This seems to be the reason why two manuscripts enhance the title by adding "on nature " to it, i.e. Galen's Book to Glaucon On (the Term) "Nature» - Kitāb Ğàlīnūs ilà Ġlùqun fì (ism) al-țabi'a: ${ }^{24}$

In Hippocrates' discourse the term "nature « $\left(\operatorname{tabi}^{-} a\right)$ conforms to four meanings:

One of them is the mixture of the body,

the second is the shape of the body,

the third is the power governing the body,

and the fourth is the motion of the soul. ${ }^{25}$

The list is then elaborated in a way similar to the one in Ibn al-Tayyib's commentary. The existence of such lists in the literature commenting on the most basic Galenic treatises makes it almost certain that the Arabic translators of Galen were greatly aware of the polysemy of the term »nature«, and this awareness must have left traces on their translations.

The person most associated with the Arabic Galen translations is Ḥunayn ibn Ishāa (d. 873). He was a native speaker of Syriac, spent time away from the Abbasid capital Baghdad, where he had already started his medical career, to improve his Greek and composed original works in Arabic. Hunayn was a physician, philosopher and Christian theologian, and translated Aristotelian and Galenic treatises into Syriac and, to a lesser extent, into Arabic. ${ }^{26}$ His writings, and in particular the Epistle on the Account of What was Translated of Galen's Books According to his [i.e. Hunayn's] Knowledge and of Some which were not Translated

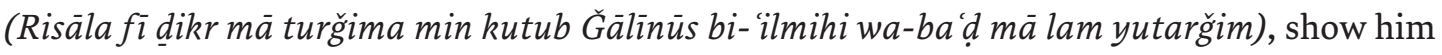
to have been well informed about the philosophical as well as the medical teachings in Alexandria and the Byzantine world. ${ }^{27}$ About the medical education he had the following to say:

23 See Stephanus, Commentary, ed. Dickson, 22-23; and the Arabic versions of the Ğawāmi and of Yahyā al-Naḥwī, for which see Garofalo, Nature.

24 I have consulted the following four manuscripts: MSS London, Wellcome Library, Or 62, 1b4-7; Tehran, Kitābhāneye Markazì-ye Dānešgāh 4914, 28a2-3; London, British Library, Add 23407, 72b8-10; and Istanbul, Sulaymaniye Kütüphanesi, Fatih 3538 (according to Sezgin's facsimile edition of the Ğawämi, I, 137.5-6). The first two manuscripts call the summary a Ğàmi, whereas the other two call it a Ğawāmi and add On Nature (or On the Term "Nature") to it. The passage quoted above reads:

$$
\text { إسمى الطبيعة يجرى في كلام ابقراط على أربعة أوجه أحدها مزاج البدن والثاني هيئة البدن والثالث القوّة المدبّرة للبدن والرابع حركة النفس }
$$

25 An almost identical list appears in al-Kindì, see n. 2 above.

26 For Ḥunayn's Syriac and Arabic Galen translations, see Watt, Why.

27 For the philosophical teaching, see Hunayn's Rare Sayings of the Philosophers (Nawādir al-faläsifa), only extant as excerpts in al-Anșarī's Aphorisms of the Philosophers (Ādäb al-falāsifa), ed. Badawī, esp. 41-44. In his Epistle (Risāla), Hunayn provides some information about how the Alexandrians arranged and read the Galenic books, see ed. and trans. Lamoreaux, 14, 18, 20, 24, 30, 38. 
These [i.e. the books listed so $\mathrm{far}^{28}$ ] are the books to the reading of which they used to restrict themselves in the place of medical instruction at Alexandria. They used to read them in the order in which I have presented them. They used to gather each day for the reading of a lesson from them and then endeavor to understand it, even as today our Christian colleagues gather each day in the places of instruction known as the "school" [al-aškül transliterating the Greek scholē] for the reading of a lesson from the books of the ancients. As for the other books, they used to read them only individually, each one by himself, after having received training in the ones that I have mentioned, even as our colleagues today read the commentaries on the books of the ancients. (Hunayn, Risāla, trans. Lamoreaux, 38-40)

Apart from such insights into the Alexandrian teaching activities, the Epistle contains short descriptions of all the Galenic treatises Hunayn knew of, as well as mentions of the existing translations into Syriac and Arabic and indications of by whom and for whom they were translated. ${ }^{29}$ Information on the Alexandrian summaries or Ğawämi of the Galenic treatises is, however, sparse. In this regard the account of the Epistle may be complemented with a remark made more than a century later, at the end of the tenth century, by the physician and bio-bibliographer Ibn Ğulğul: ${ }^{30}$

[The Alexandrians] abridged all of Galen's books and turned them into abstracts and summaries [al-ğumal wa-l-ğawāmi ], but without changing the original texts, in order to facilitate for themselves their memorization and study. Hunayn the translator found these books both in their original form and in summaries, and this is how they can still be found to this day. (trans. Gutas, Aspects, 37, slightly adapted)

Although Ibn Ğulğul does not say so explicitly, his report seems to suggest that Hunayn and his circle translated the Galenic originals as well as the Alexandrian summaries. This sits well with the manuscript tradition which ascribes the majority of the Arabic Galen translations to Hunayn. There is, however, a caveat: in the same way as original compositions, translations are often ascribed to a more famous translator in order to enhance their authority, importance and prestige. Wrong attributions may occur easily in the case of Hunayn's nephew Hubayš ibn al-Ḥasan, who also translated Galenic treatises into Arabic and whose translations were, according to the Epistle, sometimes corrected by Hunayn. This is due to the Arabic rasm, i.e. the mere undotted outline of Arabic words, of the name Hubayš which

28 Namely On the Sects, The Art of Medicine, On the Pulse for Beginners, Therapeutics to Glaucon, On Bones for Beginners, Anatomy for Beginners [including On the Dissection of Muscles, of the Nerves and of Veins and Arteries], On the Elements according to Hippocrates, On Mixtures, On the Natural Faculties, On the Diseases and Symptoms [including Differences of Diseases, Causes of Diseases, Differences of Symptoms, and Causes of Symptoms], On Affected Parts, The Large Book on the Pulse [including Differences of Pulses, Diagnosis of Pulses, Causes of Pulses, Prognosis by Pulses], On the Differences of Fevers, On Crises, On Critical Days, and On the Therapeutic Method. For this and different lists of the sixteen books of the Galenic curriculum, see Overwien, Medizinische Lehrwerke, 11-14.

29 The Epistle has survived in two different recensions, an earlier (B) and a slightly more recent one (A), and a short epitome (C). According to the recent study by Lamoreaux (in the introduction to his edition of Hunayn's Risāla, xviii-xxvi), both recensions date to the last few months of Hunayn's lifetime and both contain additions which were added, to each version independently from the other, after Hunayn's death.

30 For the Arabic text, see the entry on the Alexandrian Sages (al-Hukamä' al-iskandarānìiñ) in Ibn Ğulğul, Țabaqāt, ed. Sayyid, 51-5-7. 
is particularly close to the rasm of the name Hunayn. Therefore the name of the nephew may be misread and interpreted as the name of the more famous uncle. Some confusion between Hunayn and Hubayš may also have taken place in the case of the Arabic translation of $O n$ Diseases and Symptoms to which we shall now turn.

\section{The Arabic Translation of On Diseases and Symptoms ${ }^{31}$}

\section{The Title}

On Diseases and Symptoms is a compilation of four originally separate Galenic treatises. According to the information provided by Hunayn in the Epistle, it was the Alexandrians who combined the four treatises under a single title which they chose based on the predominant subject, namely the Book of the Causes (Kitäb al- Ilal). Particularly interesting is Hunayn's remark about the title which was given to the book in the Syriac tradition:

As for the speakers of Syriac, they entitled them [the four originally separate treatises] Causes [al-ilal] and Symptoms [al-a rä $d]$. Such a title is not appropriate for the book and quite faulty. If they wanted to fill out the title, they ought to have added and Diseases [al-amrād]. (Hunayn, Risāla, trans. Lamoreaux, 24)

This remark is interesting because it clearly indicates that in the ninth century Hunayn in no way associated the term 'illa (pl. ilal, from the root ' $l-l$ ) with the meaning "disease " which it has in classical as well as in modern Arabic and which is even attested in the Graeco-Arabic translation literature. ${ }^{32}$ If he had, he may even have interpreted the Syriac title as Diseases and Symptoms..$^{33}$ In the earliest recension of the Epistle (B), the title appears in the form ascribed to the Alexandrians, i.e. as Book on the Causes (Kitäb al-'Ilal), whereas the two other recensions (A and $\mathrm{C}$ ) use the "Syriac" title about which Hunayn complained, i.e. Book on the Causes and Symptoms (Kitäb al-'Ilal wa-l-a'räd). In the manuscript tradition, ${ }^{34}$ the title has undergone some further change and reads Book on the Things outside Nature known as the Book on the Causes and Symptoms (Kitäb fì al-ašy à' al-ḩäriğa 'an al-țabía al-ma' rüf bi-kitāb al-'Tlal wa-l-a'räd). The new element appearing in the title, namely "On the Things outside Nature" may be explained by the Galenic curriculum of the sixteen books. In the curriculum there are five subgroups of books: (1) four introductory books, (2) four books about the

31 At least two different $\breve{G} a w a \bar{m} i$-versions exist as well. One of them has been edited as a facsimile edition by Sezgin (see vol. II, 130-244); the other one is preserved in the Princeton manuscript that I discuss below and that also contains the Arabic translation of the Galenic original. It is often the case that Ğawämi $i$-versions of the same Galenic treatise differ considerably from one another.

32 See Ullmann, Wörterbuch I, 731-733. If Hunayn does indeed reject the meaning »disease« for illa, its usage in any Galen translation may be taken as an indication against his authorship of this translation.

33 In Syriac, the root ' $-l-l$ does not mean »disease«. It may do so only due to a later calque from the Arabic, see Maclean, Dictionary, 239.

34 See Sezgin, GAS III, 89-90 and the two MSS which I have used (on which see below), as well as MS Tehran, Kitābhāne-ye Markazī-ye Dānešgāh 4914, fol. 196b. 
natural things, (3) six books about the things outside nature, (4) one book about preserving the natural, and (5) one book about treating the unnatural. The Book on the Causes is the first listed in the third subgroup, as may be seen in the listing of the sixteen books in a version by Yahyā al-Nahwī: ${ }^{35}$

Know that the sixteen (books) are divided into two parts. Among them there is that which takes the place of an introduction to the consideration of the theory and practice of the medical art. They are the first four, I mean the Book on the Sects, the Book on the Small Art, the Book on the Pulse and his Book to Glaucon. The (books) considering the theory and practice of medicine are twelve books. Among them, four consider the natural things (al-ašyä' al-țabi' ìa), and they are the Book on the Elements, The Mixture, The Natural Faculties and The Anatomy. Six of them consider the things outside nature (al-ašyà' al-häriğa 'an al-țabi'a), and they are the Book on the Causes and Symptoms, The Aching Places, The Great Pulse, The Crisis, The Days of Crisis and The Fevers. One of them considers that which preserves the natural things, and it is the Book on the Regimen of the Healthy, and another consider that which allays the things which are outside nature, and it is the Book on the Method of Treatment.

It seems as if the heading of the third subgroup has been transferred to its first treatise and thus given the Book on the Causes its new name. This may be interpreted as evidence that the Arabic translations of Galen's treatises were, at least for some time, arranged, copied and transmitted according to the Galenic curriculum. One, unfortunately very late example (mid-seventeenth century) is the Princeton manuscript of our treatise ${ }^{36}$ which contains precisely the six books on the things outside nature.

As for the four originally separate treatises which were combined to form the Book on the Causes, they are listed in Hunayn's Epistle (B) in the following form: The Kinds of Diseases (Așāf al-amrād) in one section (i.e. maqāla 1 of the composite text), The Causes of Diseases ('Ilal al-amräd) in one section (i.e. maqāla 2 of the composite text), The Difference of Symptoms (Ihtilāf al-a'räd) in one section (i.e. maqāla 3 of the composite text) and The Causes of Symptoms (Asbāb al-a'rād) in three sections (i.e. maqālāt 4-6 of the composite text). A tendency towards harmonisation is already detectable in the later recension (A) of the Epistle in which the third maqāla is entitled The Kinds of Symptoms (Așnäf al-a räạ). It continues in the manuscript tradition in which the title of the second maqāla is changed into Asbāb al-amräd. ${ }^{37}$

35 The identity of this Yahyā al-Naḥwī or Johannes Grammatikos is still disputed, even if it seems certain that he is not Johannes Philoponus, who is also called Yahyā al-Naḥwī in the Arabic tradition. See Gannagé, Philopon, 556563. The Arabic text of his abridgement (ihtișär) of the sixteen books of the Galenic curriculum is preserved in MS London, British Library, Arundel Or. 17 (or Or. 444) and contains at its beginning (2b4-11) the following passage:

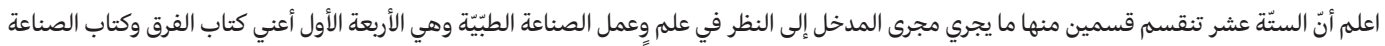

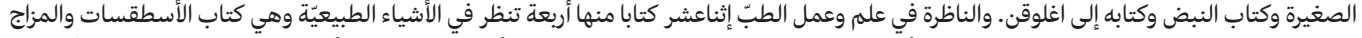

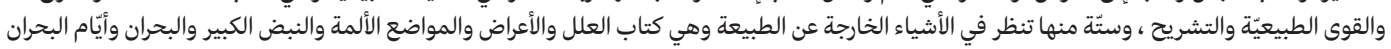

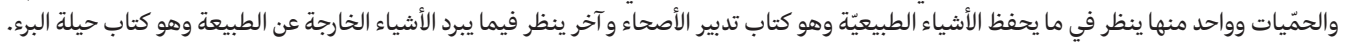
When presenting his abridgement of the Book on the Causes further on (fol. 69b3), Yahyyā al-Naḥwī entitles it Book on the Causes, Symptoms and Diseases (Kitäb al-Tlal wa-l-a räḍ wa-l-amräd).

36 On the Princeton manuscript, see below.

37 With regard to this change, one may even speculate that later generations, unlike Hunayn, associated the term illa, pl. ilal strongly with the meaning »diseases « and wanted to avoid a phrase which could also be interpreted to mean "the diseases of the diseases « and thus be taken as an example of unintelligible medical jargon. 


\section{The Contents ${ }^{38}$}

At the beginning of On Diseases and Symptoms, i.e. in the originally separate treatise The Kinds of Diseases, Galen defines health and disease and distinguishes different classes of diseases either according to the body parts which are affected, i.e. the homoiomerous body parts (e.g. arteries, veins, nerves, flesh) or the organs (e.g. heart, brain, liver, eye), or according to the kinds of affections, i.e. imbalances affecting the homoiomerous parts, and inappropriateness in formation, in the number of parts, in size or in composition affecting the organs. In the treatise The Causes of Diseases, Galen examines what may cause excessive heat, cold, dryness and moisture and what may cause diseases affecting the organs in the four ways mentioned in the previous book. He also lists a further class of diseases common to homoiomerous body parts and organs, namely the dissolution of their unity. In the treatise The Kinds of Symptoms, Galen aims at distinguishing symptoms in the same way as he has done with diseases and starts by defining various crucial terms, i.e. condition (hâl), activity $(f i l),{ }^{39}$ affection (äfa, hadat, infi $\bar{a}$ al), health (sihha), disease (marad), cause (sabab), and symptom ('arad). Then Galen divides the symptoms into conditions of the body (hâlāt al-abdān), damage to the body's activities (madärr $l i-l-a f^{\prime} a \bar{l}$ ) and things resulting from the two former such as noises of the body. He establishes two main classes of symptoms. The symptoms of the first class affect the activities of the soul (af'all li-l-nafs), the psychic (nafsānì) activities, and the symptoms of the second class affect the activities of nature (af'all li-l-tabi'a), the physical or natural ( $\operatorname{tab} i \bar{i})$ activities. For each of these classes, Galen then lists and describes a number of subclasses. These subclasses and their causes are also dealt with at length in The Causes of Symptoms, whereby its first section (i.e. maqaila 4 of the Book on the Causes) focuses on the sense organs, the second (maqāla 5) on unnatural movements, and the third (maqāla 6) on digestion.

\section{The Manuscripts Used ${ }^{40}$}

There is still no critical edition of the Arabic translation of On Diseases and Symptoms. For my translation samples in the appendix, I have used two manuscripts that are easily accessible in digitised form and that can be dated to different periods of the transmission of the treatise. This confirms that the Arabic text has remained stable and that the manuscripts chosen represent the version normally used.

38 For the Greek text, see Kühn's edition, vol. 6 and 7; and Gundert's edition (with German translation) of On the Differences of Symptoms. For an English translation of all four treatises, which thus conveniently covers the extent of the Arabic Book on the Causes, see Johnston's translation of Galen, On Diseases and Symptoms. There is a second English translation of the Causes of Diseases by Grant in Galen, On Food and Diet.

39 In the majority of cases, the Arabic translation does not distinguish between ergon and energeia, which are both translated as $f i$. I have opted to translate $f i l$ in the sense of ergon as "action " and in the sense of energeia as "activity«. For a discussion of the Greek terms and their English translation, see Johnston's introduction to his translation of Galen, On Diseases, 29-30. There, he cites a passage from The Method of Treatment (ed. Kühn, X, 43) in which Galen says: »For it is agreed then, in this case, by all men, not only by doctors but also by those they meet, that it

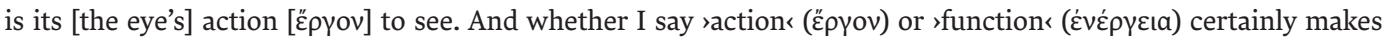
no difference now in this case." The corresponding passage in the Arabic translation of The Method of Treatment in MS Paris, BnF, Arabe 2855, fol. 20b5-6, uses only the term $f i l$ and explains that in Greek the term is expressed by different words.

40 For a list and description of the other existing manuscripts of the Arabic translation, see Overwien, Orientalische Überlieferung, 113-115. For the Ğawāmi, see Sezgin, GAS III, 148. 
Paris, Bibliothèque nationale de France (BnF), Arabe 2859

The Paris manuscript contains two Galenic treatises: On the Sects of Medicine for Beginners (Fi firaq al-tibb li-l-muta 'allimin) (fols 1-11a), which is, as we have seen, the first treatise of the Galenic curriculum, and On the Things outside Nature known as the Book on the Caus-

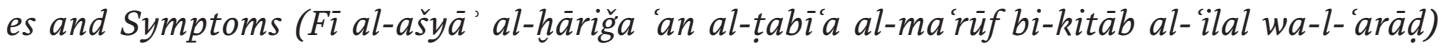
(fols 12a-86b). If the dating to the beginning of the eleventh century suggested by de Slane and Vajda holds, it would be the oldest manuscript of our treatise. ${ }^{41}$ However, both scholars also mention that the dates written at the end of the two treatises (fols 11a and 86b) were scratched and replaced by the hiğri date 232, which corresponds to the year 846 or 847 of the Common Era. They further refer to the ownership statement on the title page, which gives the name of Ibn Sinā and the year 407 h (1016/7). Yet, this Avicennian statement is clearly a forgery. ${ }^{42}$

The folios in the second half of the manuscripts are in disorder. The correct order can be reconstructed as the following: fols $12 b-51 b, 68 a^{43}-b, 60 a-67 b, 69 a-70 b, 52 a-59 b, 71 a-86 b$.

\section{Princeton, University Library, Islamic Manuscripts, New Series $1532^{44}$}

As mentioned above, the Princeton manuscript contains precisely those six treatises of the Galenic curriculum which consider the things outside nature and thus provides evidence that Galen's writings were copied and read in accordance with this curriculum until the mid-seventeenth century. Interestingly, the manuscript contains not only the Arabic translations of each of the six treatises, but also the corresponding Alexandrian summaries, i.e. Ğawāmi: The arrangement of the texts is remarkable in that each section (maqāla) of the translation of

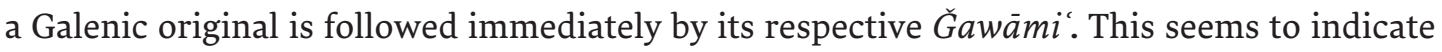
that the Ğawami $i$ played an important role in the studying of the original Galenic treatises.

41 De Slane, Catalogue, 515; Vajda, Notices manuscrits Arabe 2845-2874, 39. See the digital reproduction of the manuscript's microfilm at https://gallica.bnf.fr/ark:/12148/btv1b11002054f. However, neither de Slane nor Vajda give any argument for their dating. Should they have relied on the ownership statements, their dating would have to be rejected as these statements have been tampered with.

42 A consultation of the manuscript in Paris clearly showed that part of the ownership statement has left traces of ink on the facing page, which is of European paper and recent date. Therefore, it cannot have been composed by Ibn Sinā in the eleventh century. Also suspicious is the fact that Ibn Sīnā's name is spelt Husayn and not al-Husayn, the established form. Gacek (Arabic Manuscripts, 109) lists this particular ownership statement as an example of a forgery. The same must also hold true for the two other ownership statements which are found on the title page of the Paris manuscript, i.e. one of Buhtišū' and another of 'Alī b. Ibrāhīm.

43 In the upper margin of 68 a the last sentences of $51 \mathrm{~b} 23-28$ are repeated in a script similar to the one of the main body of the text. This probably indicates that this misordering was introduced rather early, most likely before the manuscript came to Paris (for additions made there would probably look rather different).

44 See the digital reproduction of the manuscript's microfilm at http://arks.princeton.edu/ark:/88435/cz3opw240. 
The contents of the manuscript are as follows: ${ }^{45}$

- The Book on the Things outside Nature known as the Book on Causes and Symptoms (Kitäb

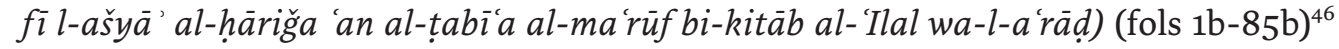

- Galen's Book on the Knowledge of the Inner Places when Harm occurs in them, known as

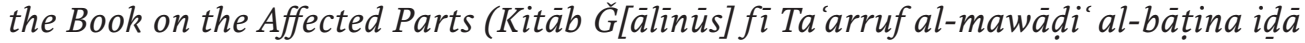
hadața bihà āfa wa-huwa al-ma 'rüf bi-Kitāb al-A'd̄à' al-ālima) (fols 85b-198a)

- Galen's Book on the Pulse (Kitäb Ğ[älīnūs] fì l-Nabd) (fols 198a-297a) ${ }^{47}$

- Galen's Book on the Kinds of Fever (Kitāb Ğ[älīnūs] fï Așnäf al-hummayāt) (fols

297b-328b)

- Galen's Book on Crisis (Kitāb Ǧ[älīnūs] fì l-Buḥrān) (fols 329a-378b)

- Galen's Book on the Days of Crisis (Kitāb Ğ[àlīnūs] fì Ayyām al-buḥrān) (fols 378b-411a)

The colophon at the end of the third treatise On the Pulse (fol. 297a) gives the date Gumāada al-Tänī 1016 hiğrì, i.e. May or June 1651 of the Common Era. As the entire manuscript is written by the same hand, it must date in its entirety to the mid-seventeenth century.

\section{The Translator}

According to the earliest version (B) of the Epistle, ${ }^{48}$ Hunayn translated the Book on the Causes for the physician Buhtišùu. Into which language is not indicated, but as the Epistle states on five other occasions that Hunayn translated something for Buhtī̌šu ' into Syriac, this is probably what happened in our case as well. The slightly younger version (A) of the Epistle has an addition according to which Hubayš translated the six sections of the treatise for Abu l-Ḥasan 'Alī ibn Yahyā into Arabic. The information in the short epitome (C) is ambiguous as the one in version (B) for it only states that the treatise was translated by Hunayn without indicating the language into which it was translated. In the extant manuscripts the translation is ascribed to Hunayn, if to anyone. ${ }^{49}$

45 For a preliminary description of the manuscript, see Mach and Ormsby, Handlist, items 76, 92, 505, 509 and 520. The second treatise is not listed.

46 In the illuminated headpiece, the title of our treatise is given in a slightly distorted form as Kitäb ilal a räd Ğālinnūs. The Arabic text of the Galenic original is not only divided into six sections (maqāla), but also into smaller chapters $(b \bar{a} b)$ which are not indicated in the Paris manuscript. The Ğawami' of the six sections are found on fols 10a-13b, 21b-23a, 31b-32a, 44a-49b, 60a-65a, 78b-85b.

47 The last two sections of the Book on the Pulse are not followed by their corresponding Gawämi, but are preceded by two very short summaries (of some lines) called ğumal.

48 For an Arabic edition of B (Istanbul, Aya Sofya 3590) and an English translation, see Ḥunayn, Risāla, ed. Lamoreaux, 24-27; for the version A (Aya Sofya 3631), see Risāla, ed. Bergsträsser, 11-12; for C (Aya Sofya 3593), see Risāla, ed. Käs.

49 See Sezgin, GAS III, 89. MS Paris, Bibliothèque nationale, Arabe 2859 mentions Abū Zayd Ḥunayn ibn Ishāq al'Ibādi al-mutațabbib as the translator on the title page (fol. 12a) and at the beginning and end of each of the six sections of the book. MS Tehran, Kitābhāne-ye Markazì-ye Dānešgāh 4914 indicates Abū Zayd Ḥunayn ibn Ishāà as the translator at the beginning of the treatise and at end of sections 5 and 6. MS Istanbul, Süleymaniye Kütüphanesi, Aya Sofya 3591 also ascribes the translation to Ḥunayn, see Ritter and Walzer, Arabische Übersetzungen 812 [14], whereas MS Princeton, University Library, Islamic Manuscripts, New Series 1532 does not mention the name of the translator. 


\section{Translating the Term "Nature"}

\section{The Method Applied in Studying the Translation}

The Thesaurus Linguae Graecae lists about one hundred occurrences of physis, i.e. physis (12 times), physin (18), physeōs (42), physei (21) and the only occurring plural form physesi (1), in the four Galenic treatises that have been brought together in the Arabic Book on the Causes, not taking into account the almost double that number of occurrences of kata physin (98 times) and para physin (85 times). ${ }^{50}$ I have listed the 94 Greek occurrences (in Kühn's edition cited from the TLG and with Johnston's English translation) and their corresponding Arabic translations (transcriptions based on the Paris and Princeton manuscripts followed by my very literal English translation) in the appendix. Each quotation is limited to an extent, by which the meaning of the cited occurrence of "nature " should become clear. In a few cases, it was possible to study a longer passage with several similarly translated occurrences of physis, thus providing more context to the reader. In such instances, the text is numbered according to the number of occurrences, e.g. "text (16-18) « which contains three instances of physis. The numbering follows the Greek because the Arabic translator sometimes adds an Arabic term for nature where it is only implied in the Greek. ${ }^{51}$ However, as the present study focuses on the Arabic renderings, the texts are arranged according to the Arabic terms that are used to render physis and thus divided into the following six groups: $\operatorname{tabi}^{-} a^{52}$ (texts 1-43), tab (texts 44-76), țabii (text 77), quwwa (texts 78-80), ğawhar (text 81) and no corresponding Arabic term (texts 82-94). Larger groups are further subdivided according to the grammatical functions in which the Arabic terms occur. Within each group or subgroup, the passages follow their sequence in On Diseases and Symptoms. Texts 95-98 present some interesting examples in which the Book on the Causes has tabi'a, where the Greek reads something else. ${ }^{53}$

\section{Results and Conclusions}

The most important and obvious difference between the two main Arabic terms used to express "nature " is that tabi ${ }^{\prime} a$ is employed when referring to an active aspect of nature, either as the agent undertaking some activity (texts 1-12) or as the possessor of, for example, an activity or instruments (texts 13-27). Tab', on the other hand, is mostly used in phrases functioning as adverbials. This suggests that the translator chooses tabi'a for rendering the Galenic meaning of the power governing the animal - for which he also uses the more explicit quwwa (power) in texts (78) and (80) - and tab for expressing the meaning of the body's mixture. This suggestion is further confirmed by the translator himself, for when Galen says that his reader should understand "nature in a particular occurrence as power governing the animal, the translator renders it by țabi'a, not țab' in text (19). This sits well with one particular instance in which the translator distinguishes surprisingly sharply between $t a b i{ }^{\prime} a$ and $t a b^{\prime}$

50 The phrase para physin is mostly translated as hāriğ 'an al-țabi'a, see texts (21-22), (24) and (95), but also as hāriğ 'an al-țab', see text (61); and kata physin as bi-l-țab', see text (96), although other renderings also occur, for example by reformulation, see text (95), or by employing the adjective țabi i, see the second occurrence in text (96). A detailed study would probably result in interesting findings, yet is beyond the scope of this article.

51 See, for example, text (1-2) in which two occurrences of physis correspond to four instances of tabía.

52 See the two occurrences of the plural form taba ${ }^{\prime} i$ in texts (31) and (34).

53 An exhaustive documentation of these occurrences is certainly worthwhile and may bring highly interesting results. In some cases, the Arabic may attest to a different Greek text than the one edited by Kühn. 
within one passage, i.e. in text (38-39) which is immediately followed by text (62-63). However, tabi' $a$ is also used to refer to bodily mixtures, namely when employed in the grammatical construction "the nature (tabi'at) of something" in texts (28), (29), (32), (33), (35)-(39), (41)-(43). In two of these examples, i.e. texts (35) and (36) the older Paris manuscript has tabi ${ }^{i} a$ where the Princeton manuscript has tab. This may indicate that the distinction between the two terms grew stronger over time and that later copyists changed the translation accordingly. At an early stage of the transmission of Galenic material, the terms seem to have been used interchangeably, as attested in the above-mentioned Ğawāmi' of On the Sects. ${ }^{54}$

In texts (30), (31), (34) and (40), the same "tabi'at of something " refers to the substance or essence of something, whereas in text (59) it is tab which refers to that very meaning. Therefore one must conclude that apart from the distinction between tabi'a and tab', the translator does in general not attempt to clarify the polysemy of nature in his model by introducing different terms, the only notable exceptions being quwwa (twice) ${ }^{55}$ and ğawhar (once). In text (34), physis is replaced by the hendiadys "ğawāhir (substances) and țabā' $i^{\prime}$ (natures)«. Another interesting hendiadys occurs in text (46), which talks about the soul's nature as its "tab' and nahiza (condition)" as if the Galenic dictum that the soul follows the mixtures of the body was somehow implied.

There is one instance, text (9), in which the translator first translates "nature " as tabi ${ }^{\prime} a$ and then adds a second occurrence of tabi ${ }^{\prime} a$ without any counterpart in the Greek, yet in a different meaning. Whereas the first tabi ${ }^{\prime} a$ most probably refers to the power governing the animal, the second one seems to refer to the composition, i.e. the mixture of a body part. If this interpretation is correct, in this case the translator does not clarify the polysemy of the Galenic text but enhances it by adding another occurrence of tabi ${ }^{\prime} a$ with a different meaning than immediately before.

Interesting are also some examples in which nature occurs in the Arabic but not in the Greek. Some of these instances may be explained by the assumption that the translator read a different Greek text than the one preserved today. In text (96), for example, the Arabic reads tabi'a where the Greek has zōon. As the Arabic reading here coincides with that of the Greek-Latin translation, ${ }^{56}$ there are two independent witnesses which make it plausible that, at least in some Greek manuscripts, tès physeōs was read instead of tou zōou. ${ }^{57}$

Most interesting are the cases in which the translator decides to omit the term "nature" and to render the Greek differently. In four of them, i.e. texts (89)-(91), he probably considers nature to refer to the essence of something and feels that translating it would not add any informational value to the phrase. These omissions can thus be seen as a simplification and clarification of his Galenic model. In seven other cases, i.e. texts (82)-(88), Galen most probably speaks about personified, i.e. demiurgic Nature, a principle that he equates with

54 See above, n. 15 .

55 The third occurrence of quwwa in text (79) is difficult to interpret. Maybe the Arabic translator had a different Greek text.

56 See Gundert's edition of Galen, Über die Verschiedenheit, 254, critical apparatus to line 11, which gives the reading of the Greek-Latin translation as "nature« but makes no mention of the different reading in the Arabic tradition.

57 Although the possibility that the two traditions interpreted the Galenic text in the same way must be considered as well. Only the Arabic tradition deviates further from the preserved Greek text, talking about the "power and care of nature as opposed to those of the animal at the end of the passage. 
the Demiurge, especially in his On the Usefulness of the Parts..$^{58}$ In text (87) he states that the nostrils are "passages of respiration invented by Nature«. This mention of nature is omitted in the Arabic, although immediately before, see text (4), nature (tabi'a) is credited with having conceived of coughing and sneezing as a strategy by which to expel irritating matter. The reason for the omission in text (87) seems to be that nature considered as inherent in the body of a living being may well be thought of as making the animal cough or sneeze as in text (4), whereas it is difficult to assume that this nature invented the nostrils and their activity, as claimed in text (87). Similarly, in text (84) the Arabic translator omits the mention of nature, but adds "wisdom and kindness" in its stead, which may be interpreted by the readers of the translation as referring to God. In the Arabic translation of On the Usefulness of the Parts, which is also ascribed to either Hunayn or Ḥubayš, these two terms are regularly mentioned when Galen talks either about the Demiurge or demiurgic Nature, which is omitted there as well. So the additional mention of "wisdom and kindness" in text (84) may be an indication that the translator interprets "nature « there as the demiurgic principle. ${ }^{59} \mathrm{In}$ text (48) where the Aristotelian-Galenic dictum that Nature does nothing in vain is referred to, the Arabic translator chooses to rephrase the text slightly and to translate bi-l-tab . Similaray, in text (53) he replaces the notion that nature has given something to the animal's parts with the formulation that the body parts are made that way by natural-disposition. In this case, the translation is particularly striking as in the immediately preceding phrase, the translator inserts tabi' $a$ to render "physical impulse" (hormē physikē), apparently having the natural power governing the animal in mind. Using țab is thus another strategy for removing any mention of demiurgic Nature from the Arabic Book on the Causes.

The suppression of demiurgic Nature may either indicate that the Christian translators of Galen did not want to refer to a demiurgic principle other than God or that they considered it a necessary change given their mainly Muslim audience and, in particular, the Muslim patrons and sponsors of the various translations. The intellectual profile of the translators and their readers that emerges from these findings is that they did not have any issues with natural powers said to govern the body or with bodily mixtures acting according to the natural qualities of the elements constituting these mixtures. ${ }^{60}$ Yet they did not agree with nature as

58 See, for example, May, the modern English translator of Galen's On the Usefulness of the Parts into English, who

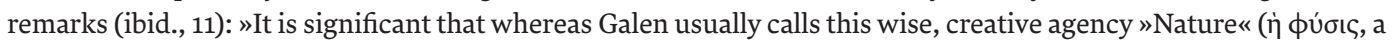
feminine noun and concept), he frequently also refers to it, with nothing to indicate any change in his thinking, as

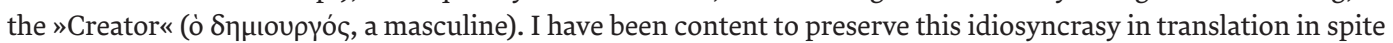
of the strangeness to our English ears of referring to one and the same person sometimes as »he« and sometimes as »she«." For a similar assessment, see Kovačić, Begriff der Physis, 210: "In Galens Texten, insbesondere in seiner Schrift De usu partium, wird die Natur als ein Agens mit kreativer Rolle außerhalb des lebendigen Organismus

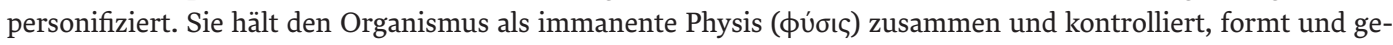
staltet ihn schon bei seinem Beginn. ... Dasselbe weise, kreative - also »Natur ( $Ф Y \Sigma I \Sigma$ ) genannte - Agens nennt

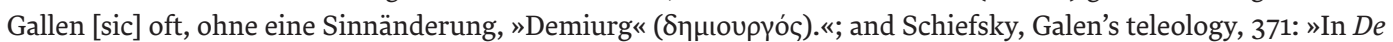
usu partium and other works, Galen describes the construction of the human body as the result of the effort of a supremely intelligent and powerful divine Craftsman or Demiurge, who exerts foresight or providence (pronoia) on behalf of living things. Galen also frequently attributes the construction of the body to a personified nature or physis, which is said to be scraftsmanliker (technikē), i.e. capable of art or craft (technē).«

59 In any case, it attests to the remarkable consistency with which demiurgic Nature was suppressed in the Galen translations done by Hunayn and his circle and on which phenomenon I am currently preparing an extensive study. On some preliminary results, see Wakelnig, Medical knowledge.

60 It would have been difficult to translate Galen, and especially On Diseases and Symptoms, replacing these Galenic notions of nature as they are fundamental to his medical theory. 
a guiding principle on a higher level, either as the Neoplatonic universal nature or as a divine agent. However, much more research needs to be done before precise conclusions can be drawn. The study of the translations of all the occurrences of physis in the Book on the Causes presented here is a first step in this direction. 


\section{Appendix}

If not stated otherwise, the Arabic transcription is based on the readings of the Paris manuscript (ب). Interesting deviating readings of the Princeton manuscript (بر) are indicated in square brackets. The orthography of hamza is adapted to modern standards.

\section{PHYSIS $\rightarrow$ TABİ'A}

\section{I. $A$. al-țabīa as acting}

Text (1-2)

Paris 28b6-12, Princeton 17b21-26

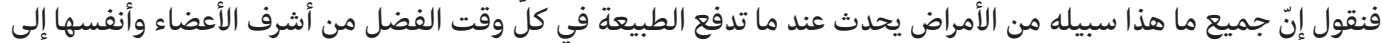

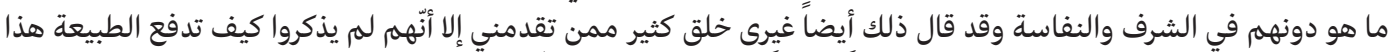

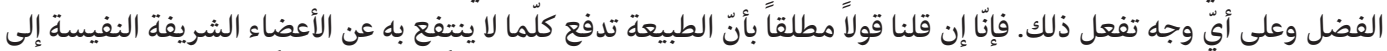

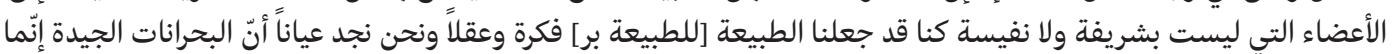

$$
\begin{aligned}
& \text { تكون في الأمراض بدفع الطبيعة. }
\end{aligned}
$$

We say that all diseases whose course is like this occur when nature expels, at all times, the superfluity from the nobler and more precious body parts to that which is below them in nobility and preciousness. Among those who have preceded me, many people other than me have also already said that, except that they have not mentioned how nature expels this superfluity and in what way (nature) does that. So, if we say in a general way that nature expels whatever is not useful from the noble and precious body parts to the parts that are neither noble nor precious, we are attributing thought and intellect to nature. We clearly find that the good crises in diseases happen through expulsion by nature.

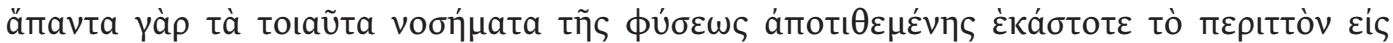

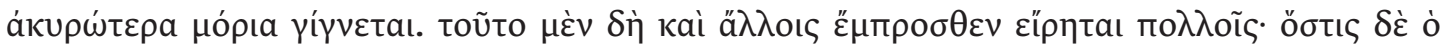

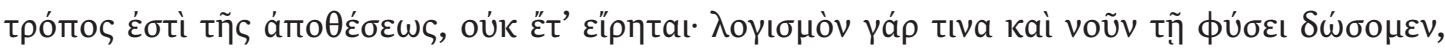

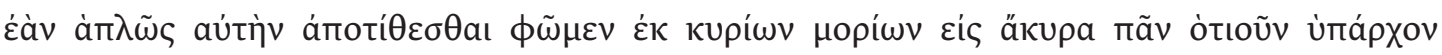

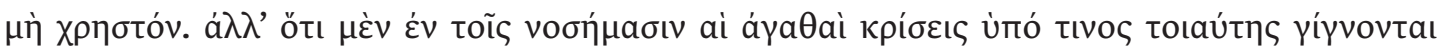

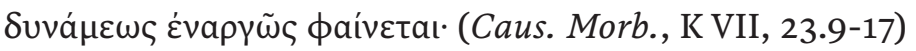

For all such diseases occur on each occasion when nature sets aside what is superfluous to less important parts. This too has certainly been said before by many others, whereas what the manner of the setting aside is, has not yet been spoken of. We shall be attributing a certain reasoning power and purpose to Nature, ${ }^{61}$ if we say that it simply sets aside anything that is not useful from the important to the unimportant parts. But that in diseases the beneficial crises come about through some such capacity is clearly seen. (trans. Johnston, 170)

61 Here $(170$, n. 48$)$ Johnston adds a note to his English translation, remarking that »In this context, and in what follows, I have taken snature to be personified. " Unfortunately he provides no further explanation except for a not very helpful reference to Brock's footnote 4, pp. 12-13 in his De facultatibus naturalibus, where it says: "As already indicated, there is no exact English equivalent for the Greek term physis, which is a principle immanent in the animal itself, whereas our term "Nature« suggests something more transcendent; we are forced often, however, to employ it in default of a better word«. In any case, Johnston's understanding differs from that of the Arabic translator who suppresses the term "nature« when he interprets it as personified, demiurgic Nature. 
Text (3)

Paris 61a19-20

$$
\text { لأنّ الطبيعة فيهنّ مشتاقة لقبول المنى لشدّة الشهوة وباللذة }
$$

For nature in [this, i.e. the uterus] longs for the reception of sperm due to the intensity of desire and by means of pleasure.

Princeton 40b10-11

$$
\text { لأنّ للطبيعة قوّة تدفع المنى نفسه وقبول المنى بشدة الشهوة وباللذة }
$$

For nature has a power, which expels the sperm itself, and a reception of the sperm with intense desire and pleasure.

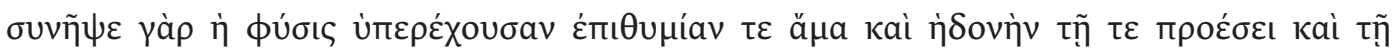

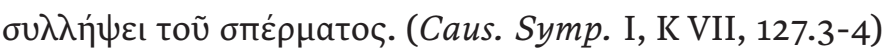

For Nature has joined powerful desire and pleasure at the same time to the emission and the gathering of the sperm. (trans. Johnston, 225)

\section{Text (4)}

Paris 52b22-28, Princeton 53b17-22

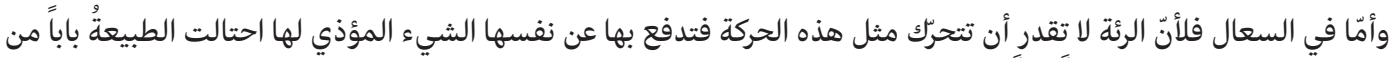

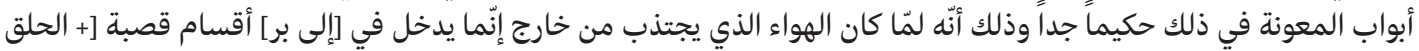

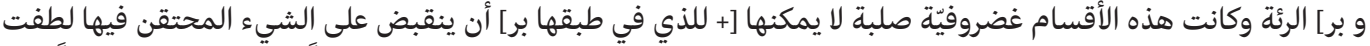

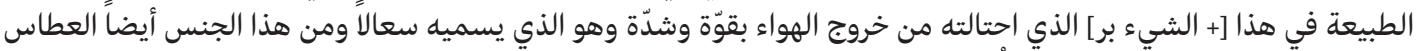

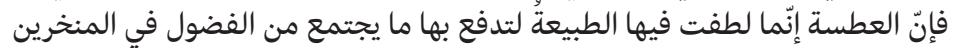

As far as coughing is concerned, since the lungs are not able to move like this and to expel the thing harming them from themselves in this way, nature has exercised one very wise sort of help with regard to that. That is, when the air, which is attracted from outside, enters into the parts of the lung's tube and when these parts are cartilaginous, hard and cannot contract upon the thing which is collected in them, nature has acted kindly by granting this help that (nature) has exercised by an expulsion of air through power and intensity. It is that which is called a cough. To this kind sneezing belongs as well. For nature has acted kindly by granting the sneeze, so that by it (nature) expels the waste that has been assembled in the nostrils, ...

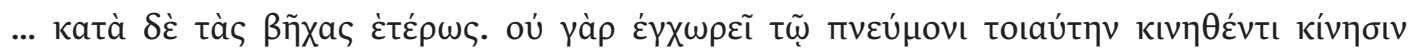

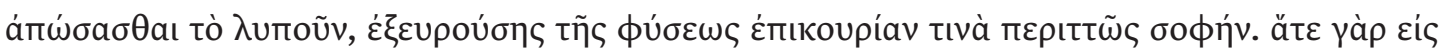

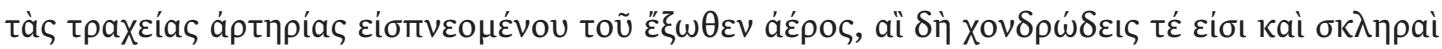

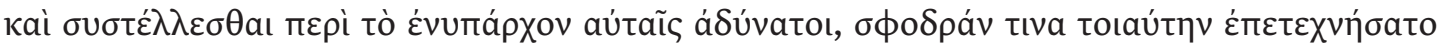

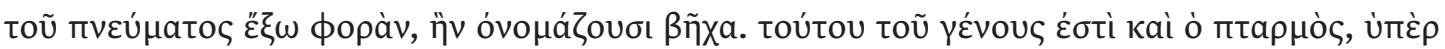

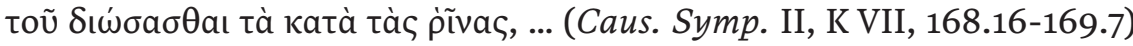


... although with coughing it is otherwise. Because it is not possible for the lung to expel the distressing agent by initiating such a movement, Nature has invented a certain extraordinarily ingenious aid. Seeing that the external air is inhaled into the bronchial tubes, which are in fact cartilaginous and hard and cannot be contracted around what is contained in them, [Nature] has contrived a certain violent passage of the breath to the outside, which they call a cough. Sneezing is also of this class, by which it pushes out things in the nostrils, ... (trans. Johnston, 248)

Text (5)

Paris 53a24-28, Princeton 54a17-20

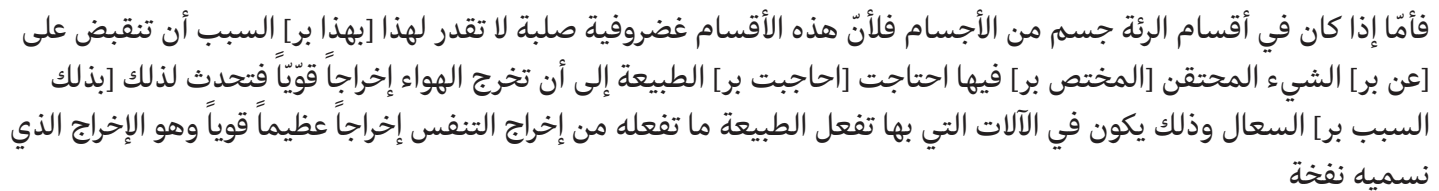

As for when there is some kind of body in the parts of the lungs, then, because these parts are cartilaginous, hard and are therefore not able to contract upon the thing which has collected in them, nature stands in need to expel the air forcefully. So it therefore brings forth a cough. That takes place in the instruments by which nature vigorously and forcefully enacts the expulsion of respiration. It is the expulsion that we call breath.

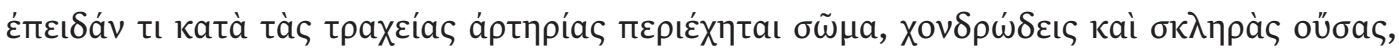

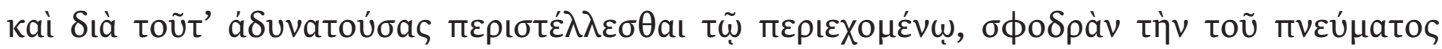

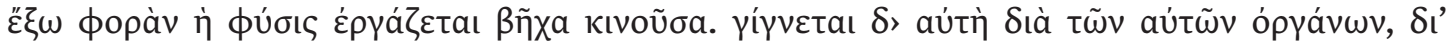

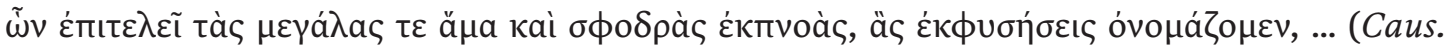
Symp. II, K VII, 171.4-10)

Whenever some body is contained in the bronchial tubes, which are cartilaginous and hard and because of this are unable to contract themselves around what is contained [in them], Nature brings about a violent impulse of the breath to the exterior, setting in motion a cough. This occurs through those same organs by which it effects the great and violent exhalations which we call remissions of breath', ... (trans. Johnston, 249)

Text (6)

Paris 54b23-24, Princeton 55b2

$$
\text { والطبيعة تبعث الحيوان على مثل هذه الحركة عند ما تريد أن تحتال في تحليل الفضول البخاريّة }
$$

Nature incites the animal to such a movement when (nature) wants to exercise skill in the dissolution of vaporous residues.

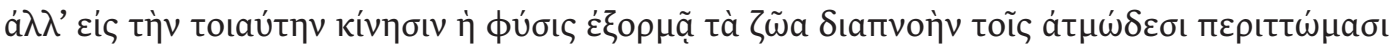
$\mu \eta \chi a v \omega \mu \varepsilon ́ v \eta$. (Caus. Symp. II, K VII, 178.2-4) 
But Nature incites animals to such a movement, contriving an outlet for the vaporous superfluities. (trans. Johnston, 252)

\section{Text (7)}

Paris 55b26-28, Princeton 56a20-21

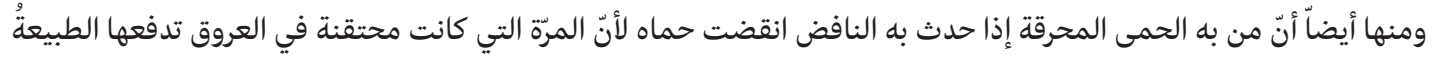

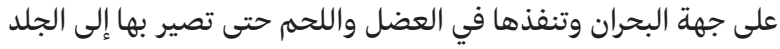

Among [the fevers] it also happens that, if a shivering fit occurs in him who has burning fever, his fever disappears. ${ }^{62}$ For nature expels the bile, which has collected in the veins, in the manner of a crisis and causes (the bile) to pierce the muscles and the flesh until it has led (the bile) to the skin.

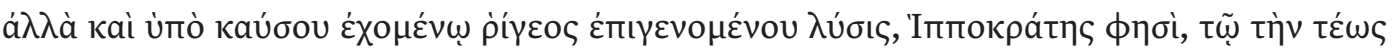

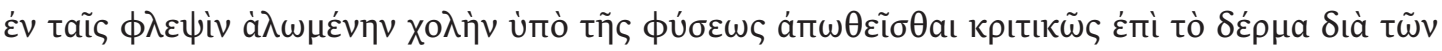
баркஸ̃v. (Caus. Symp. II, K VII, 182.14-17)

But also, in someone having a bilious remittent fever (kausos), there is lysis when a rigor supervenes, Hippocrates says, because the bile, which until then was caught up in the veins, is preferentially driven out by Nature through the flesh to the skin. (trans. Johnston, 255)

Text (8)

Paris 57b14-16, Princeton 57b13-15

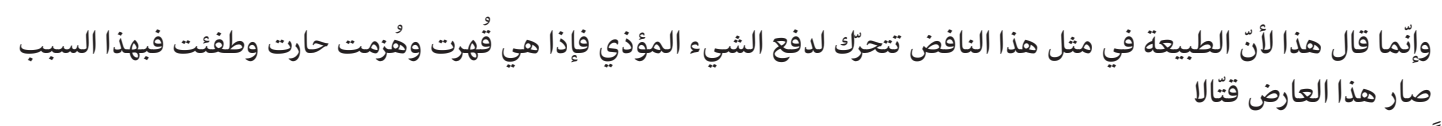

He says this because in such a shivering fit nature moves to expel the harmful thing. Then, when it is overcome and defeated, it perishes and expires. For this reason, this occurrence becomes fatal.

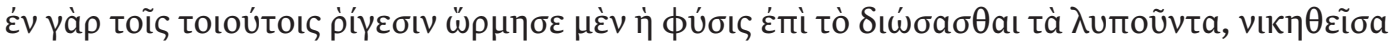

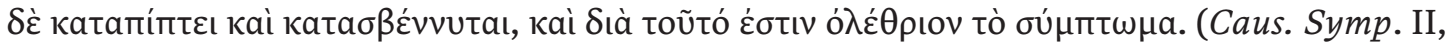
K VII, 190.8-11)

For in such rigors, Nature sets in motion distressing things for the purpose of expulsion but, having been overcome, it collapses and is quenched, and because of this the symptom is fatal. (trans. Johnston, 258)

62 The Arabic version omits the mention of Hippocrates and renders his aphorism slightly differently than in its existing Arabic translation by Hunayn, see Hippocrates, Aphorisms, ed. Tytler 37, IV.57:

$$
\text { إذا كانت بإنسان حمى محرقة فعرضت له نافض انحلّت بها حماه. }
$$




\section{Text (9)}

Paris 77a27-b3, Princeton 70a12-16

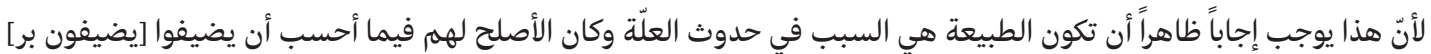

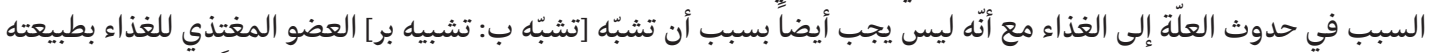

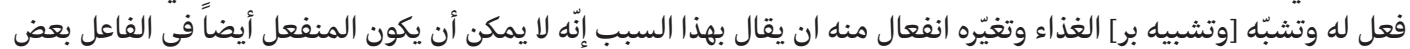

$$
\begin{aligned}
& \text { الشيء ولو كان في غاية القلّة والصغر }
\end{aligned}
$$

For this makes it clearly necessary that nature is the cause for the occurrence of the disease, yet with regard to what I consider, it would be most suitable for them to attribute the cause for the occurrence of the disease to the nutriment. Since the body part's assimilation of the nutriment to its own nature is its action and the assimilation and change of nutriment are an affection caused by it, it is still not necessary to say that because of that it is impossible that the affected may also produce something in the agent, even if it is of utmost insignificance and smallness.

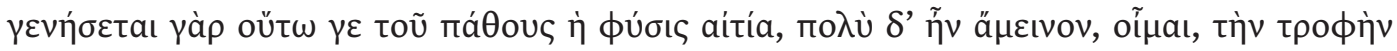

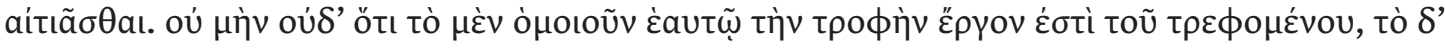

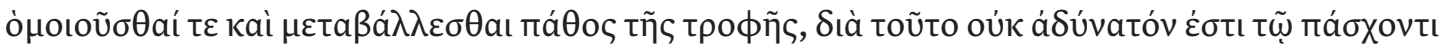

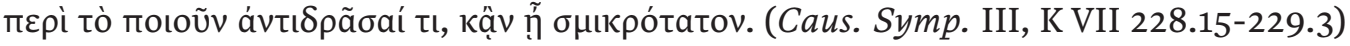

For in this way at least, nature will become the cause of the affection (pathos), whereas it were far better, I think, to attribute the cause to the nutriment. Although, certainly, the action of what is nourished is to make the nutriment like itself, whereas the affection (pathos) of the nutriment is to be assimilated and changed, it is not impossible because of this for what is acted upon to act against what affects it, even if only very slightly. (trans. Johnston, 280-281)

Text (10)

Paris 78b16-17, Princeton 71a21-22

$$
\text { وقد يكون ذلك أيضاً مراراً كثيرة من قبل الطبيعة عندما تريد أن تدفع وتنفض عنها الأشياء المؤذية لها }
$$

That is also often due to nature when it wants to expel and shake off ${ }^{63}$ from it things which are harmful to it.

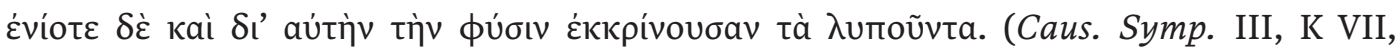
234.11-12)

... and sometimes also as a result of Nature itself expelling distressing things. (trans. Johnston, 283)

63 Here the translator uses a hendiadys. 
Text (11)

Paris 8ob5-9, Princeton 72b27-73a3

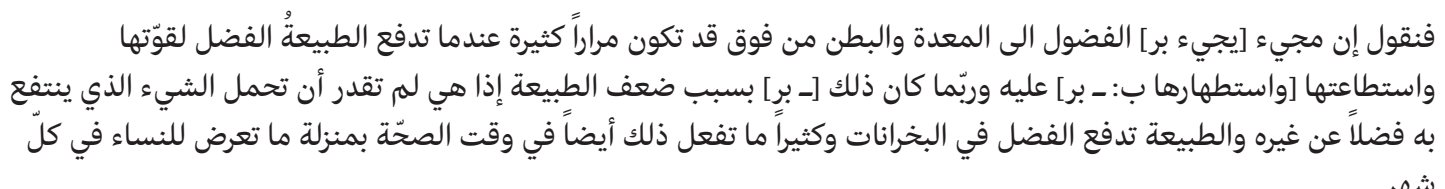

We said that the arriving of the residues towards the stomach and the belly from above often happens when nature pushes the residue with its power and its capacity away from it. Sometimes that is due to nature's weakness, when it is not able to carry the thing that is useful, let alone something else. Nature expels the residue in crises and often it also does that in times of health, e.g. what befalls women every month.

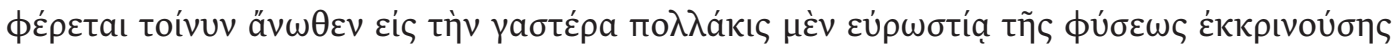

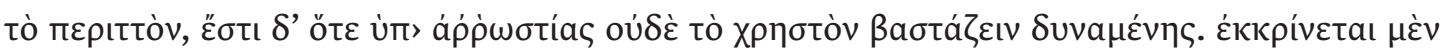

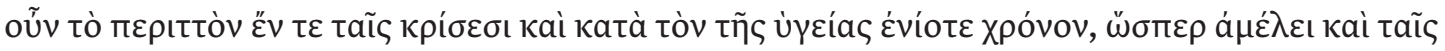

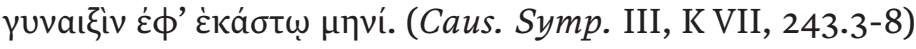

Accordingly, the superfluity is often carried from above the stomach by the strength of the natural separation, although sometimes owing to weakness it is not even able to bear what is useful. The superfluity is then separated in crises and sometimes in a time of health, as it is, of course, in women each month. (trans. Johnston, 288)

Text (12)

Paris 85b3-4, Princeton 78a18-19

$$
\text { وطبيعة البدن أيضاً على ما وصفت وربّما اعانت على تولّد الأعراض وربّما خالفت ومنعت من كونها }
$$

According to what I have described, the nature of the body also sometimes helps the generation of symptoms and sometimes hinders their coming to be.

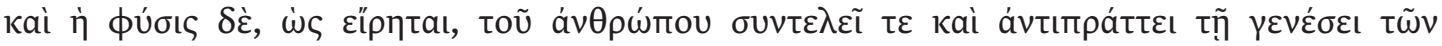

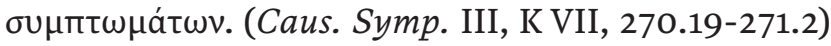

Also the nature, as has been said, of the person acts with or acts against the generation of symptoms. (trans. Johnston, 301) 


\section{B. al-țabīa as possessor}

Text (13)

Paris 36b7-9, Princeton 25b6-7

$$
\text { فنقّول إنّه ينبغي لنا أن نقسّهم ضروب [بر:ضرب] الفعل إلى جنسين أوّّلين إذ كانت الأصناف الأول من أصناف الأفعال اثنين وذلك }
$$

We say that we must divide the sorts of activity into two primary genera, since the primary kinds of the kinds of activities are two. For to them belong activities of the soul and activities of nature.

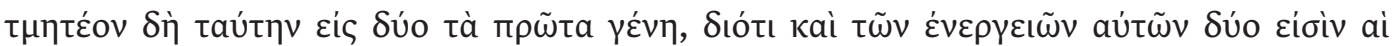

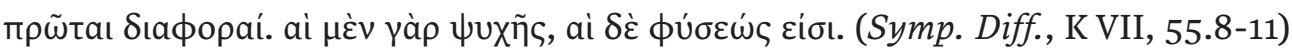

This [i.e. the activity] one must now divide into two primary classes because the primary differentiae of the activities themselves are also two in number. They are those of the soul and those of nature. (trans. Johnston, 188, slightly adapted)

\section{Text (14)}

Paris 38b18, Princeton 27a19-20

$$
\text { وذلك أنّ الأعضاء التي هي آلات للطبيعة قد [فقط بر] يعرض فيها هذه الثمانية الأعراض فقط }
$$

That is to say that the body parts which are instruments for nature are only befallen by these eight symptoms ...

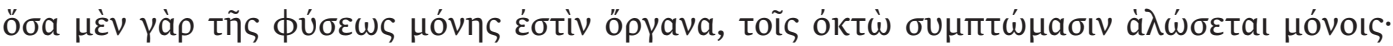
(Symp. Diff., K VII, 64.1-2)

For those that are of the physical alone will be afflicted with eight symptoms only, .... (trans. Johnston, 193)

\section{Text (15)}

Paris 43b1-2, Princeton 31a15-16

$$
\text { إذ كان كلّ واحد منها أحرى وأولى بأن يكون عملاً من أعمال الطبيعة وفعلاً من أفعالها من أن يكون مضرّةً }
$$

Since each of these [things in whose occurrence and generation there is usefulness for the body] is more appropriate and better suited for being one of the works of nature and one of its activities ${ }^{64}$ rather than being a damage.

64 It is puzzling that the Arabic translator, who had just before, see text (96), distinguished between ergon and energeia by rendering them with two separate terms, namely 'amal and $f i$, now applied the hendiadys 'amal wa-fil to render ergon alone. 


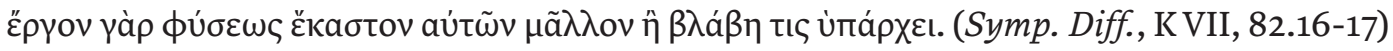

For each of these [i.e. things occurring for the purpose of benefit - E. W.] is an action of nature rather than an injury. (trans. Johnston, 201)

Text (16-18)

Paris 66a6-13, Princeton 49b25-50a2

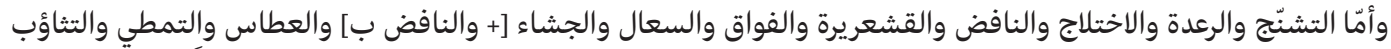

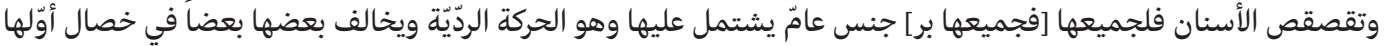

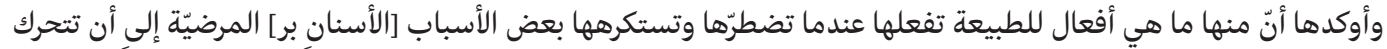

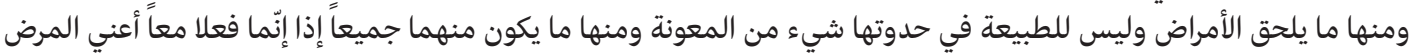

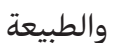

As for spasm, tremor, convulsion, shivering fit, shiver, hiccup, coughing, belching, sneezing, stretching, yawning and chattering of teeth, they all have a common genus which contains them, namely defective movement. They differ from one another in [their] properties. The first and most certain of [their differing properties] is that among [these movements] there are actions which belong to nature and which (nature) enacts when some causes of disease force it and compel it to move, and among them there is what adheres to diseases and nature has, with regard to its occurrence, no sort of help. To them belong that which is caused by both of them together, when they act together, I mean disease and nature.

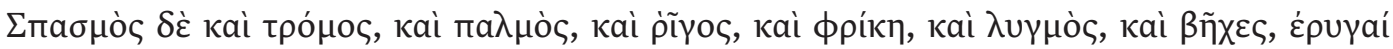

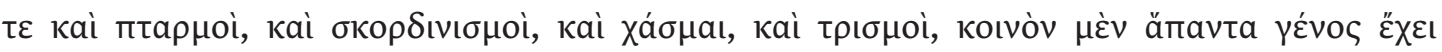

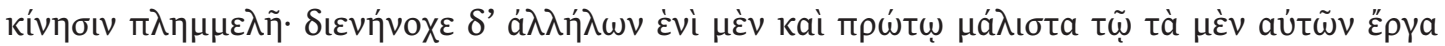

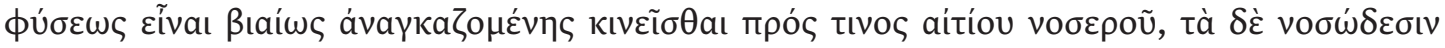

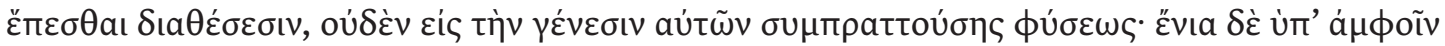

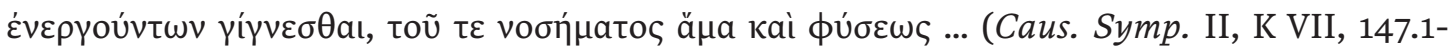
148.1)

Spasm (spasmos) and tremor (tromos), palpitation (palmos), rigor (rigos), shivering (phrike), hiccup (lygmos), coughing (bex), belching (eruge), sneezing (ptarmos), stretching (skordinismos), yawning (chasme) and rasping (trusmos) all have a common class, that of disordered movement. They do, however, also differ among themselves, especially in one primary way, in that some of them are actions of a nature compelled to move violently by a disease-making cause, whilst others [of the class of disordered movement] follow disease conditions, nature contributing nothing to their genesis. Some, however, occur in which both are operative, that is disease and nature simultaneously. (trans. Johnston, 238) 


\section{Text (19)}

Paris 66a12-14, Princeton 50a2-3

$$
\begin{aligned}
& \text { وإذا أنا قلت لك في هذا الكلام طبيعة فإفههم عني [عليّ برَ أنّّ هذا الاسم [اسهم بر] أصرفه على كلّ قوّة تُدبّر البدن إن كانت ممّا } \\
& \text { فعله [تفعل ب] بإرادتنا وإن كانت تفعل بلا إرادتنا }
\end{aligned}
$$

When I say to you "nature " in this discourse, then do understand that I employ this term to mean every power which governs the body, whether what it enacts is due to our will or whether it is acting without our will.

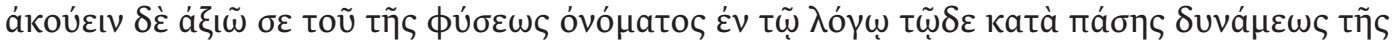

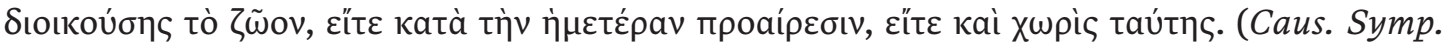
II, K VII, 148.2-4)

I would expect you to understand the term "nature " in the following discussion as relating to every power governing an animal, whether in accordance with our choosing, or apart from this. (trans. Johnston, 238, slightly adapted)

\section{Text (20)}

Paris 66b2-3, Princeton 50a13-14

$$
\text { فما دام البدن يجري مجرى الطبيعة [طبيعته بر] فليس من حركات قوّة من هذه القوى شيء عرضٌ }
$$

As long as the body proceeds in the course of nature, nothing among the movements of any of these powers is a symptom.

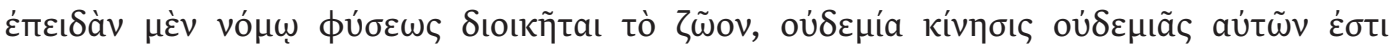
бú $\mu \pi \tau \omega \mu а \cdot($ Caus. Symp. III, K VII, 149.5-7)

When an animal is governed by the law of nature, no movement of any one of these is a symptom. (trans. Johnston, 239)

\section{Text (21-22)}

Paris 53a3-6, Princeton 53b25-27

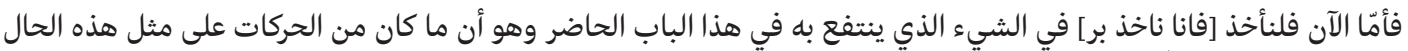

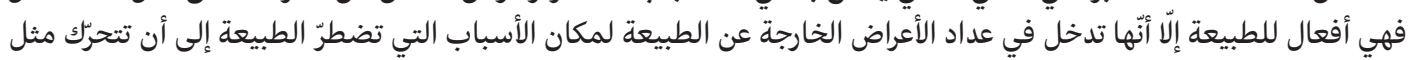

$$
\begin{aligned}
& \text { هذه الحركة }
\end{aligned}
$$

As for now, let us begin the matter which is helpful in this present discussion, and that is that the movements according to this condition are actions belonging to nature, except that they enter into the number of the symptoms outside nature because of the reasons which force nature to move in such a way. 


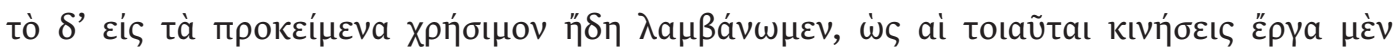

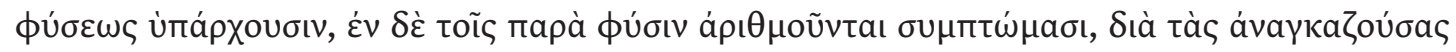

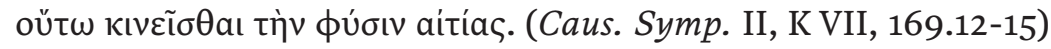

Let us accept for now what is useful to the matters put forward - that such movements are actions of Nature, although numbered among the symptoms contrary to nature because they are causes compelling Nature to move in this way. (trans. Johnston, 248)

\section{Text (23)}

Paris 53a13-15, Princeton 54a6-8

$$
\text { وأمّا في المعدة فعارض إلقىء ظاهر معروف وكثير من الناس يقول في هذه أيضاً إنّها ليست بأفعال للطبيعة [الطبيعة بر] بل إنّما }
$$

As with regard to what concerns the stomach, the occurrence of vomiting is clear and known, but many people also say about these (occurrences) that they are not actions belonging to nature, but only symptoms.

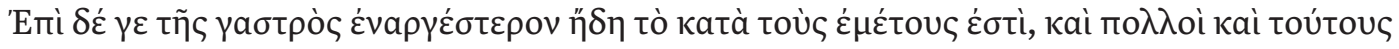

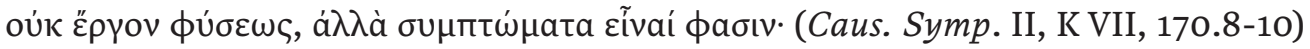

At least in the case of the stomach, what relates to vomiting is now more clear, yet many also say these are not actions of nature but symptoms. (trans. Johnston, 249, slightly changed)

\section{Text (24)}

Paris 53a15-19, Princeton 54a12-13

$$
\text { وفي الأعراض سببٌ خارج عن الطبيعة هو المحرك للطبيعة }
$$

In symptoms, a cause outside nature is the mover of nature.

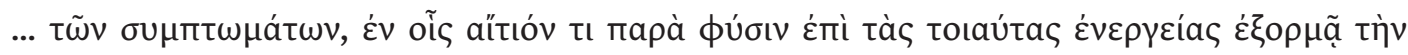

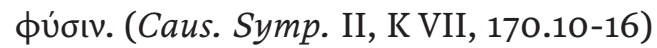

... symptoms in which some cause contrary to nature incites nature to such functions. (trans. Johnston, 249, slightly changed)

\section{Text (25)}

Paris 56a20-21, Princeton 56b10-11

$$
\text { يجري على مجرى طب طبعيته هذه فضولها في كلّ يوم دفعاً بيناً بلا أذى وبلا [ولا بر] مشقّة بالتحليل الذي لا يدركه الحسّ ما دام البدن }
$$


Yet (this expulsive power) also expels from these (organs) their residues every day in a plain expulsion without pain and without hardship through dissolution, that the senses do not perceive, as long as the body proceeds according to the course of its nature.

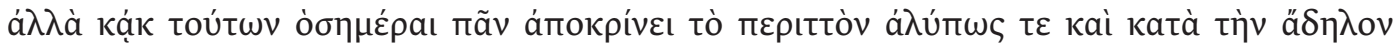

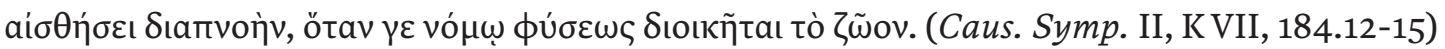

Rather, every day it also separates from these things the entire excess without disturbance and during a transpiration imperceptible to sense - whenever, that is, the animal is governed by the law of nature. (trans. Johnston, 255-256)

\section{Text (26)}

Paris 77b3-5, Princeton 70a16-18

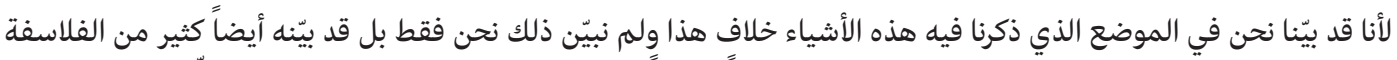

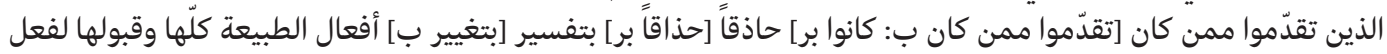

$$
\begin{aligned}
& \text { غيرها }
\end{aligned}
$$

We have already made clear a difference to that in the passage in which we have mentioned these things. Not only we have made that clear, but also many of the preceding philosophers, who were proficient in interpreting all the actions of nature and its reception of the action of others, had already made it clear.

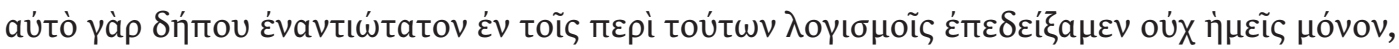

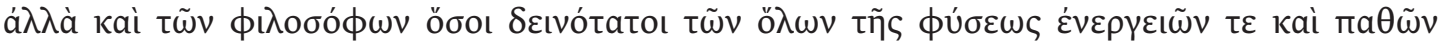

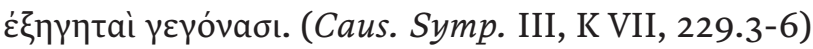

For surely we have shown quite the opposite of this in the discussions of these matters, and not only us, but also the most able of the philosophers who have been interpreters of all the functions and affections (pathos) of nature. (trans. Johnston, 281)

Text (27)

Paris 80a23-26, Princeton 72b18-20

$$
\begin{aligned}
& \text { وذلك أنّ نوع هذا الصوت نفسه يدلّ على هذين جميعاً أعنب أنّه بسبب أن حدوثه إنّما هو عن حركة الطبيعة صار يدلّ على اندفاع }
\end{aligned}
$$

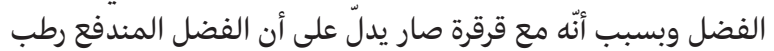

That is that the species of this sound itself indicates these two together, I mean that because its production is through the motion of nature it indicates the discharge of the superfluity, and because of its being with its rumble it indicates that the expelled superfluity is moist.

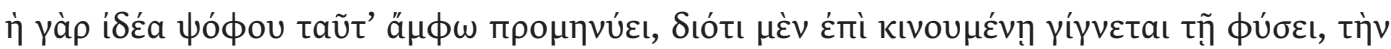

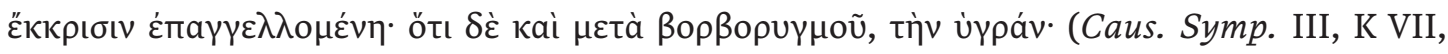
242.1-5) 
For the kind of sound indicates both these things in advance, signifying separation because it occurs in the case of a natural movement, but moisture in that it occurs along with borborygmos. (trans. Johnston, 287)

\section{C. țabìat of someone or something}

Text (28)

Paris 16b8-10, Princeton 5a2-4

$$
\begin{aligned}
& \text { وقد يحدث في البدن على ذلك المثال بعينه أمراض رطبة ويابسة عندما يتغيّر جملة طبيعة الأجرام البسيطة إلى الرطوبة أو إلى }
\end{aligned}
$$

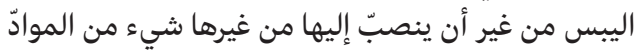

In the body there occur humid and dry diseases according to that very example when the entirety of the nature of the simple bodies is changed towards humidity or towards dryness without any material thing flowing towards them.

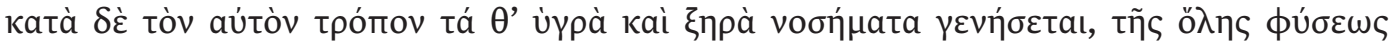

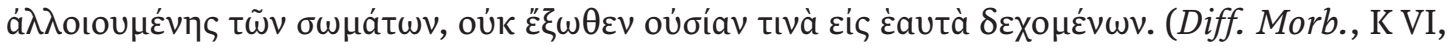
852.12-15)

In the same way, moist and dry diseases will arise when there is a change in the entire nature of the bodies but they receive no external substance into themselves. (trans. Johnston, 143)

\section{Text (29)}

Paris, 24b13-14, Princeton 14b12-14

$$
\text { متى لهم يكن للحركة من المقدار والقوّة ما يغيّر طبيعة المفاصل والعضل لمم يحدث لها أعياء }
$$

... when the movement does not have the extent and the power to change the nature of the joints and muscles, no fatigue is produced for them.

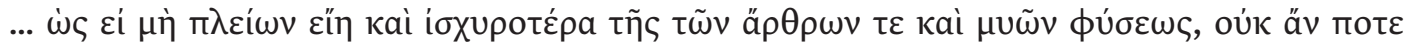

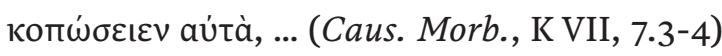

... that if the movement were not greater or stronger than the natural constitution of the joints and muscles, these would not then be fatigued at all. (trans. Johnston, 162)

Text (30)

Paris, 34b15-16, Princeton 24a9-10

$$
\text { وأمّا الشيء الذي يدخل جزء من طبيعته في الشيء الذي يكون فيقال انه سبب كونه [بكونه بر] }
$$


As for the thing, a part of whose nature enters into a thing which is generated, it is called a cause of its generation.

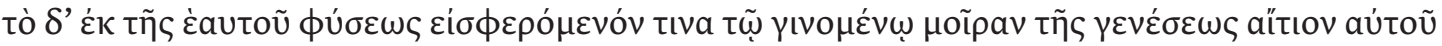
$\lambda \varepsilon \dot{\gamma \varepsilon \tau a . . ~(S y m p . ~ D i f f . ~ K ~ V I I, ~ 47.14-16) ~}$

That which from its own nature contributes some part of the genesis [of something] by its occurrence is called its cause. (trans. Johnston, 185)

Text (31)

Paris, 39a7, Princeton 27b6-7

$$
\text { لكن يجيد نظره ويتثبت في نفس [بعض بر طبائع الأمور }
$$

But to ameliorate his inspection and to verify the very natures of the matters ...

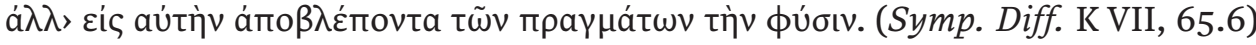

... but to focus instead on the actual nature of the matters. (trans. Johnston, 193)

Text (32)

Paris 44b8, Princeton $32 \mathrm{~b} 20$

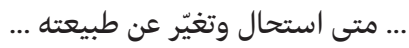

... when it is transformed and changed from its nature ....

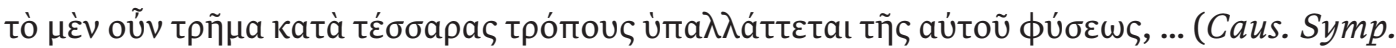
I, K VII, 88.3-4)

The aperture, then, changes its nature in four ways: ... (trans. Johnston, 207)

\section{Text (33)}

Paris 68a17-18, Princeton 39a6

$$
\text { من قبل أنّه [إنّما بر] ضدٌّ لجوهر البصر صار تجمعه جمعاً عنيفاً مستكرهاً بأكثر يحتاج إليه للرجوع إلى طبيعته }
$$

Due to being opposite to the substance of vision its coming together becomes violent and forceful more than is necessary for the return to its nature

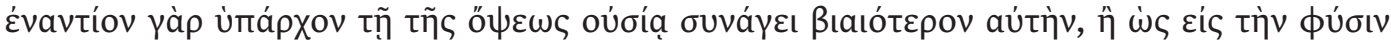

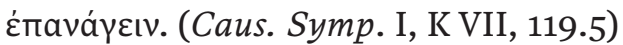


... for being opposite to the substance of vision it draws it together more violently than [allows it to] return to its nature. (trans. Johnston, 222)

\section{Text (34)}

Paris, 60a23-24, Princeton 39b26-27

$$
\text { وقد ذكرنا جواهر هذه الطعوم وطبائعها في المقالة الرابعة من كتابنا في [كتابنا في ب: كتاب بر] قوى الأدوية المفردة }
$$

We have already mentioned the substances and natures of these flavours in the fourth section of our book on the powers of simple remedies.

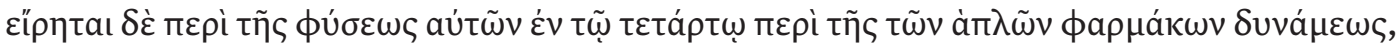
(Caus. Symp. I, K VII, 123.3)

There has been discussion about [physis - not translated by Johnston, E. W.] these things in the fourth [book] on the capacity of simple remedies, .... (trans. Johnston, 223, slightly adapted)

\section{Text (35)}

Princeton 64b12, Princeton $43 a 19$

$$
\text { وكلّما كان الطعام في طبيعته }{ }^{65} \text { [طبعه بر] أرطب كان نومه أكثر }
$$

The more food is in its nature humid, the more sleep (it gives)

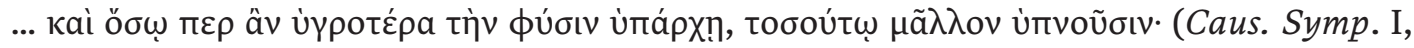
K VII, 141.12)

... and the more this should be moist in nature the more they sleep ... (trans. Johnston, 233)

\section{Text (36)}

Paris 69b23-24, Princeton $52 \mathrm{a} 13$

$$
\text { وهذه الأعضاء [+ هي الأعضاء بر] التي هي في طبيعتها [طبعها بر] لينة لين يمكنها معه [ـ بر] أن تقبل الانبساط والانقباض }
$$

Softness enables these body parts which are in their nature soft to receive the extension and contraction together with (softness).

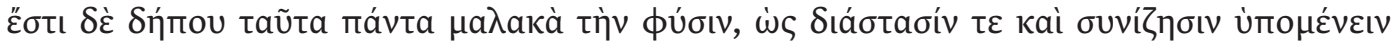

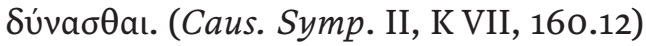

65 The reading has been corrected by a later hand and may originally have read $t-b-{ }^{-}-t-h$. 
These are, of course, all those that are soft in nature, such as to be able to undergo distention and collapse. (trans. Johnston, 244)

Text (37)

Paris, 70a13-14, Princeton 52a27

$$
\text { ونعمل على أنّه أحد شيئين إمّا خلط من الأخلاط وإمّا شيء من طبيعة الهواء }
$$

We aim at its being one of two things, either any mixture or something belonging to the nature of air.

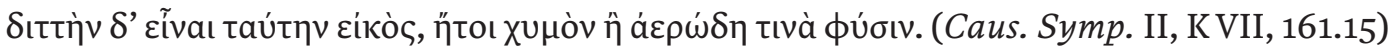

The probability in this case is twofold; either a humour or something of an airy nature. (trans. Johnston, 245)

\section{Text (38-39)}

Paris 54b2-4, Princeton 55a11-12

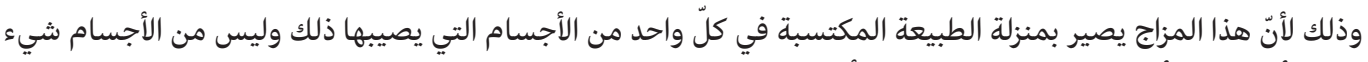

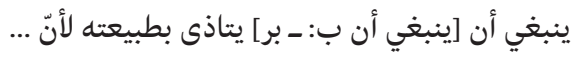

That is because this mixture occurs as the acquired nature in every one of the bodies which are affected by that. Among the bodies there is nothing which may be harmed by its nature. ...

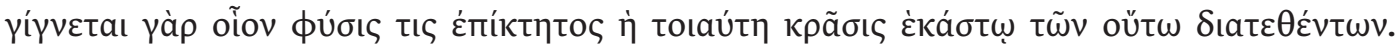

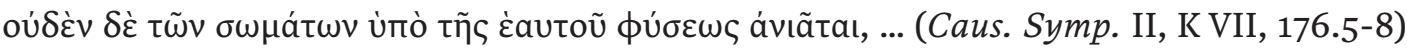

For such a mixing occurs in each of the parts so disposed as if it were some additional nature. No body is distressed by its own nature. (trans. Johnston, 252)

\section{Text (40)}

Paris, 55b10-13, Princeton 56a8-10

$$
\begin{aligned}
& \text { ومن غير أن تتمثل في ذلك أيضاً بمثال قد نجد في نفس طبيعة الأمر أنّ السبب إذا كان يتحرّك كان أذاه أكثر من أذى السبب }
\end{aligned}
$$

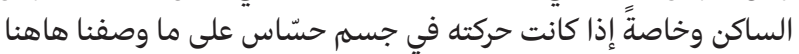

We may find in the very nature of the matter that when the cause is moved, its pain is more intense than the pain of a stationary cause, and specifically, when its movement is in a perceiving body according to what we have now described.

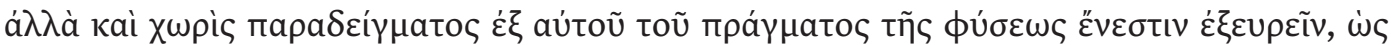

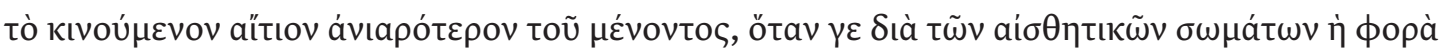

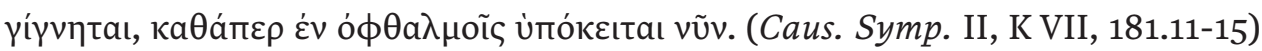


But also, apart from the example, it is possible to discover from the nature of the matter itself that a cause which is moving is more distressing than one which is stationary whenever, at least, what is borne occurs through perceiving bodies, as was just now proposed in relation to the eyes. (trans. Johnston, 254)

\section{Text (41)}

Paris 56b22, Princeton 57a5-6

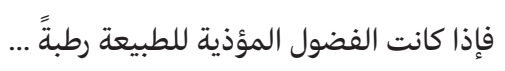

If the residues harmful to nature are humid ....

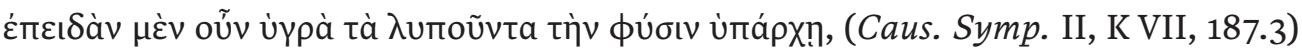

Whenever, then, the distressing things are moist in nature, ... (trans. Johnston, 257)

\section{Text (42)}

Paris 58a25-26, Princeton 58a16

$$
\text { وانطفاؤها يكون بسبب طبيعة العارض لأنّ كونه وحدوثه إنّما هو بتسلّط [بانبساط بر] البرد }
$$

Its extinction is due to the nature of the occurrence, for its generation and happening are through the prevailing of coldness.

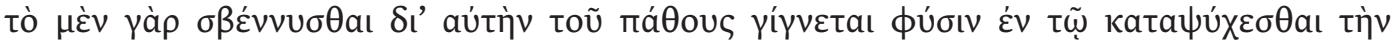

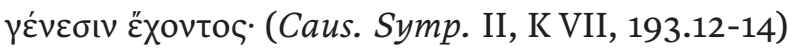

For quenching occurs due to the very nature of the affection (pathos) which has its genesis in the cooling, ... (trans. Johnston, 260)

\section{Text (43)}

Paris 86a24-25, Princeton 78a11-12

$$
\text { ومن قبل طبيعة البدن ومن قبل سرعة حسّه وإبطاء حسّه }
$$

... and due to the nature of the body, and due the velocity and slowness of its sensation ...

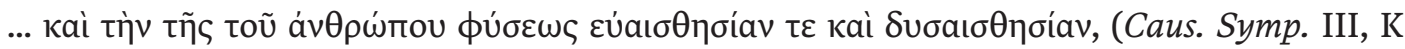
VII, 270.9-10)

... and the strong or reduced sensibility of the nature of the person ... (trans. Johnston, 301) 


\section{PHYSIS $\rightarrow$ TAB}

\section{A. țab uhu as grammatical subject}

\section{Text (44)}

Paris, 51a27-51b1, Princeton 38a25-6

$$
\text { يتغير طبعه ويفسد الفاضل فلاطون وأما الفاضل ابقراط وقد [وان بر] كان قبل الفاضل فلاطون فأنّه قال إنّ الألم إنّما يحدث بمن [بأن بر] }
$$

And this is the statement of the noble Plato. As for the noble Hippocrates, who was already before the noble Plato, he said that pain befalls him whose natural-disposition is changed and corrupted.

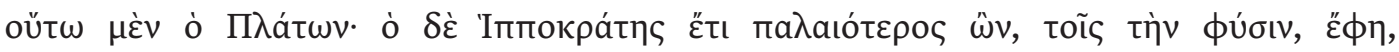

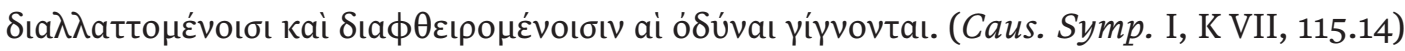

Thus, Plato. Hippocrates, who was still more ancient, said that in those who, with respect to the natural state, are changed and corrupted, pains occur. (trans. Johnston, 220)

\section{Text (45)}

Paris 59a13-16, Princeton, 58b26-59a1

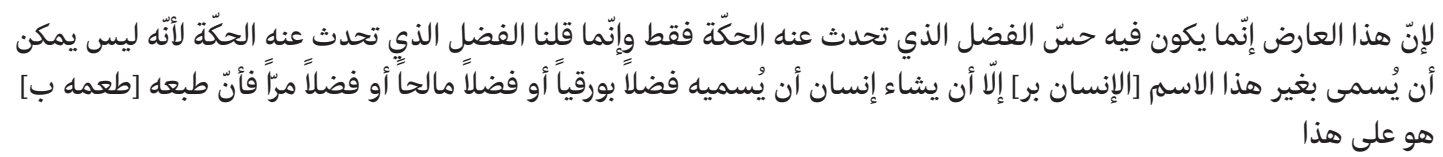

For in this symptom there is the sensation of superfluity, from which alone the itching is produced and we say »the superfluity from which itching is produced«. For it is not possible to call it any other than this name unless someone wishes to call it nitrous superfluity or salty superfluity or bitter superfluity, because its nature ${ }^{66}$ is accordingly.

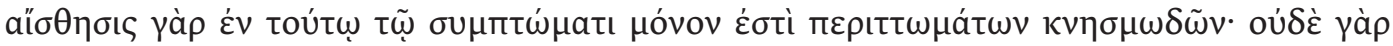

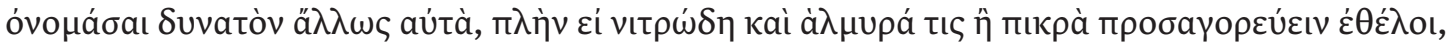

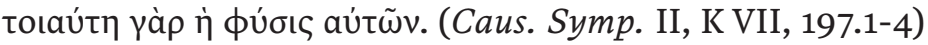

For in this symptom the sensation is of superfluities associated with itching alone, in that one cannot give a name to these in any other way unless one wishes to speak of something alkaline or salty or sharp for such is their nature. (trans. Johnston, 261)

66 The Paris manuscript reads »taste«. 


\section{B. al-țab’a as an adverb}

Text (46)

Paris 58a24-25, Princeton 58a15-16

$$
\text { وذلك عندما تكون النفس ضعيفة الطبع والنحيزة فيعرض لها عارض قويّ شديد فتطفئ بغتةً وتختنق }
$$

That (also occurs) when the soul is weak in its natural-disposition (tab) and condition (nahiza) and something strong and intense befalls it, then it is suddenly extinguished and strangled.

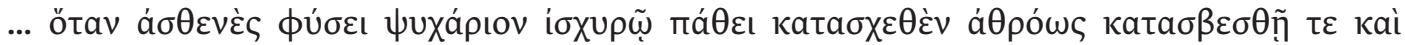
кatamviүñ. (Caus. Symp. II, K VII, 193.10-12)

Accordingly, some have also died in sudden fears, whenever the soul, weak in nature and possessed suddenly by a strong affection (pathos), is quenched and smothered. (trans. Johnston, 260)

\section{Text (47)}

Paris 73a1-2, Princeton 66a13-14

$$
\text { وما كان منه تضرب فيه الحموضة فحدوثه عن الأغذئة الباردة البلغمية الطبع }
$$

(Of that is also) that in which acidity moves and its occurrence is from the cold foodstuff phlegmatic in natural-disposition

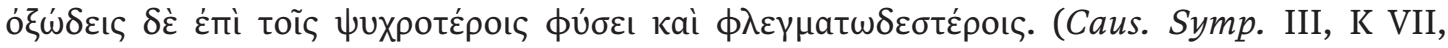
209.1-2)

... the acidic [`corruptions occur - E. W.] in the case of those that are colder in nature and more phlegmatic. (trans. Johnston, 270) 


\section{C. bi-l-țabi - adverbial}

Text (48)

Paris 17a25-28, Princeton 5b12-14

وذلك أنّا إذا كنّا قد بيّنا أنّه لمَ تُجعل واحدة من هذه الخصال بالطبع عبثاً ولا باطلاً بل إنّما جُعلت كلّها ليكون العضو يفعل ما يفعله بجملة أجزائه فعلاً أجود وأوثق

That is, since we have already made clear that none of these properties is by natural-disposition made in vain and futile, but all of them are made so that the body part acts as it acts through the entirety of its parts in a better and safer way, ...

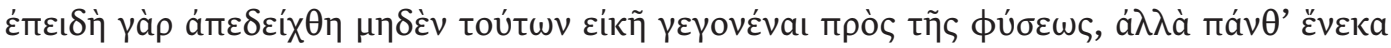

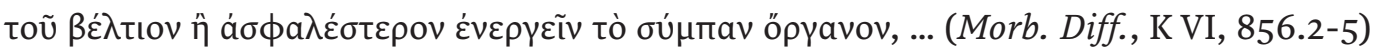

For since it has been shown that none of these [parts] has been created by nature without a purpose, but in all cases for the better or safer functioning of the whole organ, ... (trans. Johnston, 144-145)

\section{Text (49)}

Paris 18b8-9, Princeton 6b11

$$
\text { عندما يحدث في العضو الأملس بالطبع خشونة أو في العضو الخشن بالطبع ملوسة }
$$

... when roughness occurs in a by natural-disposition very smooth part or smoothness in a by natural-disposition rough part.

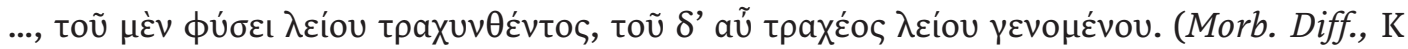
VI, 861.6-7)

... when what is by nature smooth becomes rough, or again, when what is by nature rough becomes smooth. (trans. Johnston, 147)

\section{Text (50)}

Paris 29b13-14, Princeton 18b16-17

$$
\text { وذلك أنّ من كانت ساقاه بالطبع منتصبين على استقامة بأكثر ممّا ينبغي ... }
$$

That is he whose two legs are by natural-disposition straight according to a straightness which is more than it should be ...

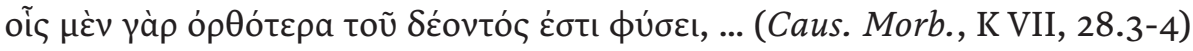

In those whose legs are straighter than is natural, ... (trans. Johnston, 172) 
Text (51)

Paris 46b25-26, Princeton 34b9-10

$$
\text { وذلك لأنّ الرطوبة الجليديّة تكون في هاؤلاء على غاية الصفاء والنقاء [والبقاء بر] بالطبع }
$$

That is because the ice-like humour is in these by natural-disposition at the utmost clarity and purity

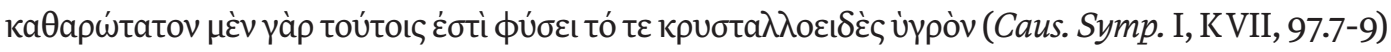

For in these the crystalline humour is very pure in nature, .... (trans. Johnston, 211)

Text (52)

Paris 63b9, Princeton $42 \mathrm{~b} 2$

$$
\text { إمّا بسبب علّة فيهما [بهما بر] وإمّا بالطبع }
$$

... either because of a cause in these two or by natural-disposition

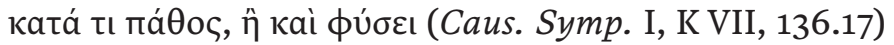

... either in some affection (pathos) or by nature (trans. Johnston, 231)

\section{Text (53)}

Paris 54b17-20, Princeton 55a24-27

$$
\begin{aligned}
& \text { وفي جميع هذه الأعراض وأشباهها [واسبابها بر] يخبر [يحس برك] من يعرض له به باختلاف في بدنه واضطراب فيتمطّون ويمدون }
\end{aligned}
$$

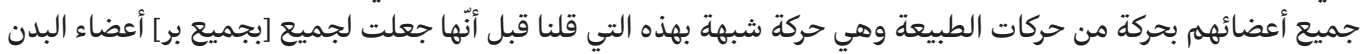

$$
\begin{aligned}
& \text { بالطبع لتنجوا بها من الأذى وتبقى على سلامتهات. }
\end{aligned}
$$

In all these symptoms and their likes whoever is affected by them tells about discordance and disturbance in his body. So (these affected people) stretch and expand all their body parts by one of nature's movements, which is a movement similar to the one about which we have said before that it has been made for all the body parts by natural-disposition so that by it they may be saved from harm and maintain their health.

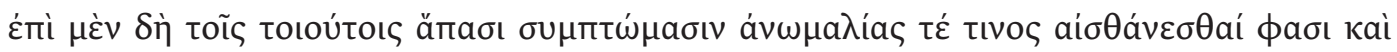

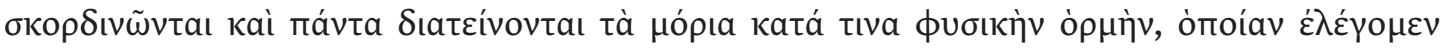

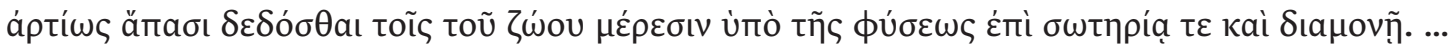
(Caus. Symp. II, K VII, 177.11-16)

Certainly, in all such symptoms, people say they sense some irregularity, or they stretch the limbs, or they extend all parts under some physical impulse, the kind we were saying just now has been given by Nature to all the parts of the animal for the purposes of safety and preservation. (trans. Johnston, 252) 


\section{Text (54)}

Paris 78b7-8, Princeton 71a13-14

وهذه خصال تكون في بعض الناس بالطبع من قبل رداءة الخلقة في الأرحام

These are traits which are generated in some people by natural-disposition on the part of a badness of inborn disposition in the womb.

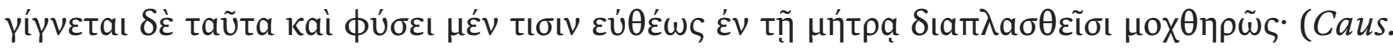
Symp. III, K VII, 233.16-17)

And these occur naturally at the earliest times (i. e. at birth) in some who are formed badly in the womb. (trans. Johnston, 283)

\section{Text (55)}

Paris 79b15-16, Princeton 72a14-15

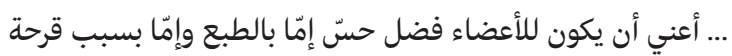

I mean that the body parts have a superfluity of sensation either by natural-disposition or because of an ulcer.

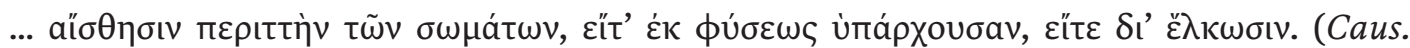
Symp. II, K VII, 238.18-239.1)

... an excessive sensation of bodies, whether this is from nature, or due to an ulcer. (trans. Johnston, 286)

\section{Text (56)}

Paris $85 a 9$, Princeton $77 a 8$

إذا كان كذلك بالطبع

... when it is by natural-disposition like that

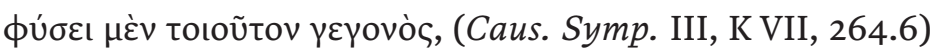

... being such in nature (trans. Johnston, 298) 
Text (57)

Paris 85a16-17, Princeton 77a13-14

$$
\text { وأمّا سؤ مزاج الأرحام فقد يكون بالطبع ويكون من طريق حدوت العلل وكذلك كثافة الأرحام }
$$

As for a misfortune in the mixture of the uterus, it may be by natural-disposition and by way of the occurrence of illnesses, and that is like the thickening of the uterus.

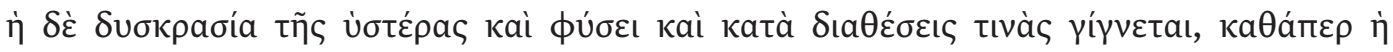
пuкvótпs. (Caus. Symp. III, K VII, 264.15-16)

A dyscrasia of the uterus occurs both naturally and in certain conditions, just like a thickening. (trans. Johnston, 298)

\section{D. other prepositions + al-țab i}

Text (58)

Paris 29a1, Princeton 18a11-12

$$
\text { ... وإمّا من قبل أنّه قد يحتاج في الطبع إلى أن يكون كذلك بمنزلة الجلد. }
$$

... or on the part of its being in the natural-disposition that it is necessarily like that, like the skin.

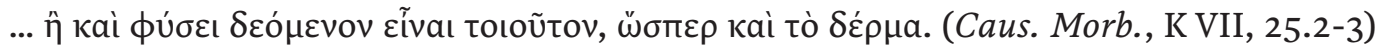

... or is required by nature to be such [a part], like the skin. (trans. Johnston, 171)

\section{Text (59)}

Paris 34a14-16, Princeton 23b14-16

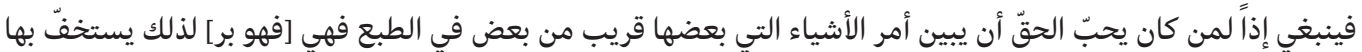

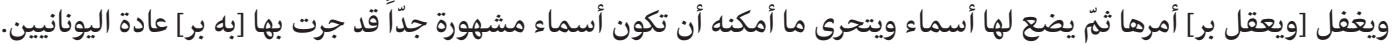

He who is truth-loving must make clear the matter of the things which are close to one another in their natural-dispositions (or essences) wherefore no importance is attached to them and their matter is passed over. Then he gives them names and aspires as much as he can that they are very well-known names which the practice of the Greeks entails.

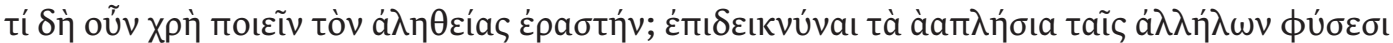

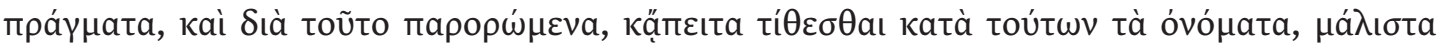

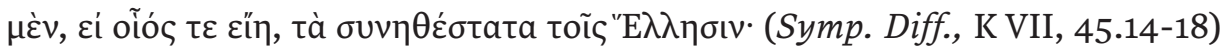


What, then, ought one who loves the truth do? Point out the matters that are similar to the natures of others and owing to this are overlooked, and then put names to these, especially, if it be possible, those most customary among the Greeks. (trans. Johnston, 183)

\section{Text (60)}

Paris, 45a14-15, Princeton $33 a 17$

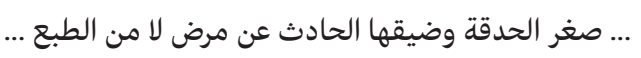

... the smallness of the pupil and its narrowness produced by a disease, not by the natural-disposition ...

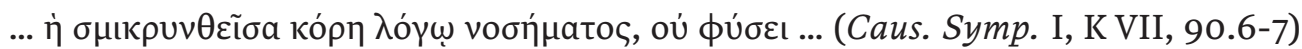

... a pupil made smaller by reason of disease, not nature ... (trans. Johnston, 208)

\section{Text (61)}

Paris, 51a24-27, Princeton 38a22-25

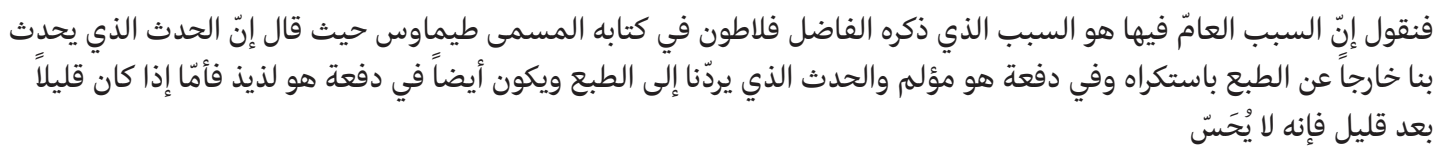

So we say that the common cause for this is the cause which the noble Plato has mentioned in his book called Tima 'ùs when he says that an occurrence that befalls us outside the natural-disposition by force and suddenly is painful, whereas an occurrence that returns us to the natural-disposition and is also sudden is pleasant. As to when it is gradual, it is not perceived.

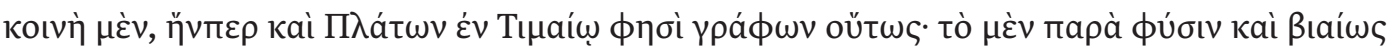

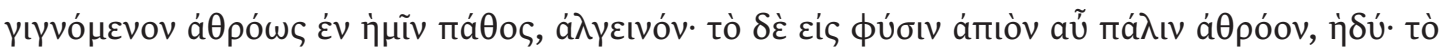
$\delta \varepsilon \dot{~ n ́ p \varepsilon ́ \mu a ~ к a i ~ \kappa a t a ̀ ~ \mu ı к р o ̀ v, ~ a ́ v a i ́ \sigma \theta \eta t o v . ~(C a u s . ~ S y m p . ~ I, ~ K ~ V I I, ~ 115.9-13) ~}$

Common is what Plato also says in the Timaeus, writing thus: 'An affection (pathos) contrary to nature occurring in us violently and intensely is pain; the return to the natural state on the other hand, when it is intense, is pleasure. What is slow and slight is not perceived. (trans. Johnston, 220)

\section{Text (62-63)}

Paris 54b4-6, Princeton 55a13-15

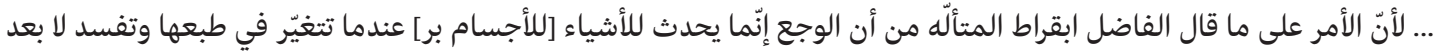

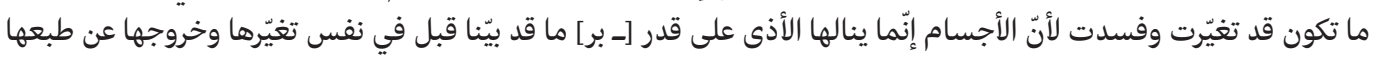


For the matter is according to what the excellent and adored Hippocrates says, namely that the pain is only produced for the things when they change in their natural-disposition and are corrupted not after they have changed and been corrupted. For the bodies only receive harm according to the amount, which we have made clear before, with regard to the essence of their change and their being outside of their natural-disposition.

...

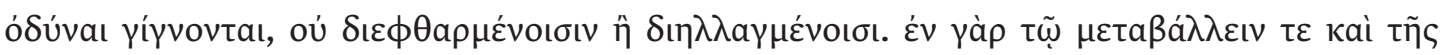

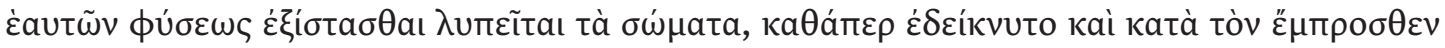
入ópov. (Caus. Symp. II, K VII, 176.8-13)

As Hippocrates said, pains occur in those things that are being changed or destroyed in their nature, not in those that have already been changed or destroyed. For in being changed, and in departing from their own nature, bodies are distressed, as was also shown in the earlier discussion. (trans. Johnston, 252)

\section{E. țab' of something or someone}

\section{Text (64)}

Paris 25b24-25, Princeton $15 \mathrm{~b} 10$

$$
\text { ... الأشياء التي في طبعها أن تكون غذاءً للنار ... }
$$

... the things in whose natural-disposition it is to be nourishment for fire, ...

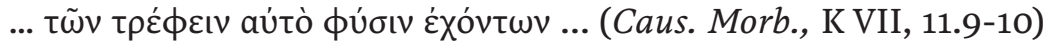

... those things that are of the nature to nourish it ... (trans. Johnston, 164)

Text (65)

Paris, 26b5-6, Princeton 16a10-11

$$
\text { وجميع ما يوكل ويشرب أيضاً مما له في طبعه فصل برودة يكون سبباً للمرض البارد }
$$

All that is also eaten and drunk of that that has an excess of coldness in its natural-disposition is a cause for cold disease.

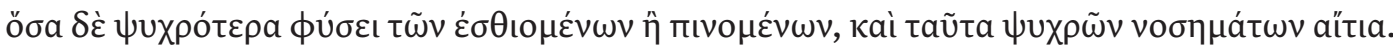
(Caus. Morb., K VII, 13.17-14.1)

However, many of the things eaten and drunk that are too cold in nature are also causes of cold diseases. (trans. Johnston, 165) 


\section{Text (66)}

Paris 31a16-17, Princeton 20a2-3

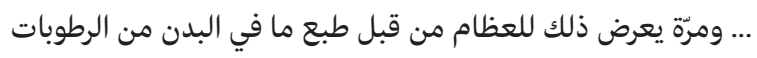

... and sometimes that befalls the bones from the part of the natural-disposition of the fluids in the body.

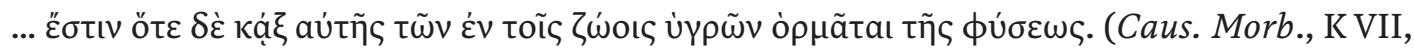
$33.13-14)$

... or sometimes being set in motion from the very nature of the fluids in the animals. (trans. Johnston, 176)

\section{Text (67)}

Paris 42b26, Princeton $30 b 18$

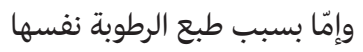

... or due to the natural-disposition of the humidity itself

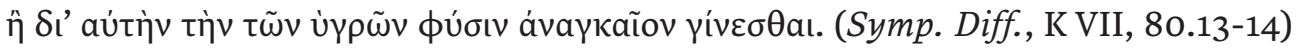

... or necessitated by the actual nature of the humours. (trans. Johnston, 200)

\section{Text (68)}

Paris, 69a28-b2, Princeton 51b20-22

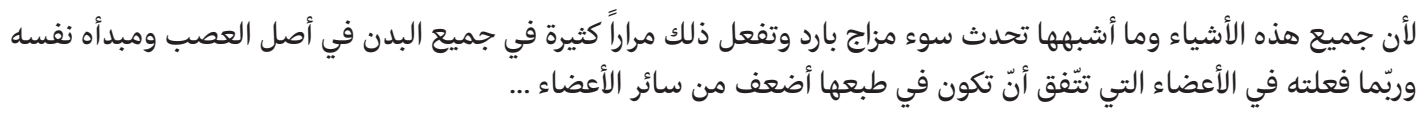

For all these things and what resembles them generate a bad cold mixture. They do that often in the entire body at the source and beginning of the nerves themselves, and sometimes they may do that in the body parts which happen to be in their natural-disposition weaker than the other body parts ...

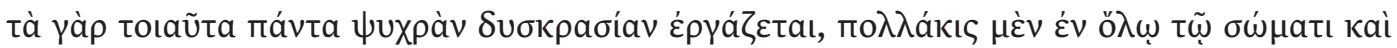

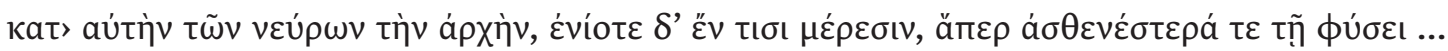
(Caus. Symp. II, K VII, 158.14-17)

All such things bring about a cold dyscrasia, often in the whole body, and in relation to the actual arche of the nerves, but sometimes in certain parts, which are weaker in nature ... (trans. Johnston, 243) 


\section{Text (69)}

Paris, 54b13-14, Princeton 55a21-22

$$
\text { وذاك أنّ الإنسان يحس في باطن بدنه كلّه وفي عمقه كأنّ فيه شيئًا غريباً من طبعه منكراً عنده مبثوثاً }
$$

That is, man perceives in the interior of his whole body and in its depth as if there is in him something alien to his natural-disposition, unfamiliar to him and spread

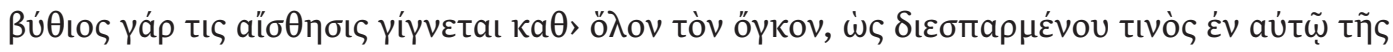

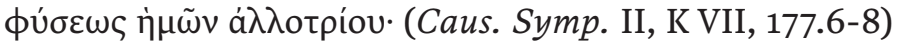

For some deep sensation occurs in relation to the whole mass as if something alien to our nature has been dispersed in it. (trans. Johnston, 252)

\section{Text (70)}

Paris 55a19-20, Princeton 55b21

$$
\text { ........ وإمّا أن يكون في طبعه عسر الحسّ }
$$

... or in that it is in its natural-disposition difficult to be affected ...

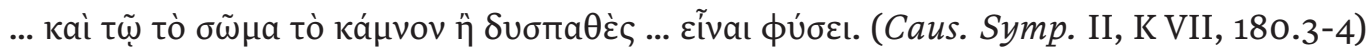

... as well as in the nature of the fatigued body, whether it is not easily affected ... (trans. Johnston, 253)

\section{Text (71)}

Paris 57b16-17, Princeton 57b15-16

$$
\text { ذلك لأنّ المرّة السوداء في طبعها هي خلط بارد }
$$

That is because black bile is a cold mixture in its natural-disposition

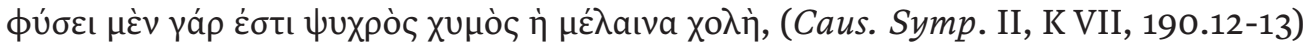

For black bile is by nature a cold humour, ... (trans. Johnston, 258)

\section{Text (72)}

Paris, 74a9-10, Princeton 67a14-15

$$
\text { وفسادها عامّةً يكون بتغيّرها إلى الدخائّة وفساد كلّ واحد منها خاصّةً يكون بحسب ما هو عليه في طبعه }
$$

Their corruption is, in general, due to their changing into vapours, whereas the corruption of each one of them is, specifically, according to what it is like in its natural-disposition 


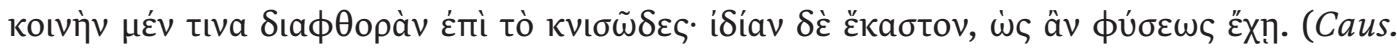
Symp. III, K VII, 213.18-214.1)

...the usual corruption tending towards steaming although each [food] has a specific [corruption] according to its nature. (trans. Johnston, 273)

\section{Text (73-74)}

Paris 74a18-20, Princeton 67a21-23

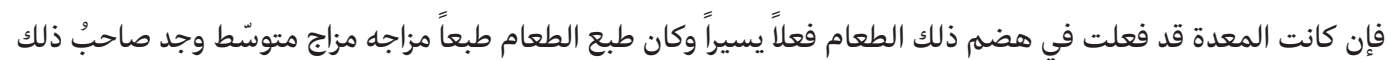

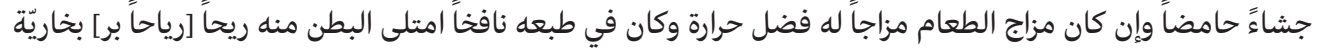

If the stomach does some little work in the digestion of that nutriment and the natural-disposition of the nutriment is a natural-disposition whose mixture is a balanced mixture, he who has that is found belching and acid, and if the mixture of the nutriment is a mixture which has an excess of heat and is flatulent in its natural-disposition, the stomach is filled by it with vaporous wind.

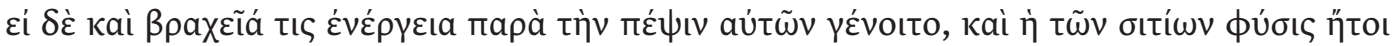

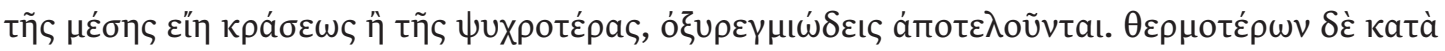

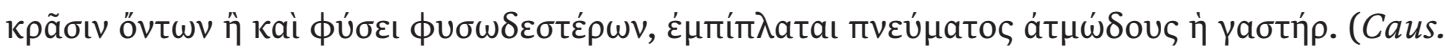
Symp. III, K VII, 214.10-15)

And if some slight function occurs during the digestion of these, and the nature of the foods is either of indeterminate mixture or of one more cold, heartburns (oxyrgemiodes) are brought about. When the foods are hotter with respect to mixture, or also more flatulent in nature, the stomach is filled with vaporous pneuma. (trans. Johnston, 273-274)

\section{Text (75)}

Paris, 76a14, Princeton 69a9-10

$$
\text { وذلك أنّ بعض الأغذية في طبعها مولّدة للسوداء ... }
$$

That is that some foodstuffs are more generative for melancholy in their naturaldisposition ...

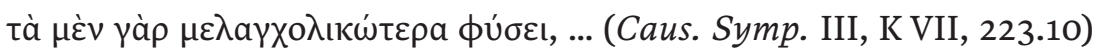

For some are more melancholic in nature, ... (trans. Johnston, 278) 


\section{Text (76)}

Paris 79b24-25, Princeton 72a23-24

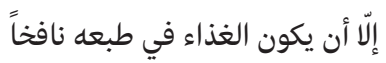

... unless the food is flatulent in its natural-disposition

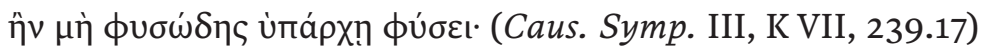

... unless it is vaporous by nature. (trans. Johnston, 286)

\section{PHYSIS $\rightarrow$ TABĪI $\bar{I}$}

Text (77)

Paris 51b1-3, Princeton 38a26-38b1

$$
\text { ممّا شأَّه ألمس يرضّ ويحدثخ فيها التغييرات عن الحال الطبيعيّة من قبل عنف مماسة ما يلقى البدن من الشيء الحارّ أو البارد أو شيء }
$$

In the sensation of touch, there occur changes away from the natural condition due to the vehemence of some contact between the body and something hot or cold or something whose matter it is to crush, to tear, to cut, to expand or to erode.

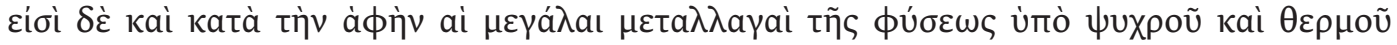

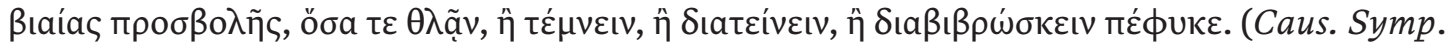
I, K VII, 115.18)

And with respect to touch, there are major changes of nature from the violent visitation of cold and heat, and such things as are disposed to crush, cut, stretch or erode. (trans. Johnston, 220) 


\section{PHYSIS $\rightarrow$ QUWWA}

Text (78)

Paris 82b6-7, Princeton 74b15-16

وهاهنا شيء هو خلاف هذه العلّة وهو ما يكون في العرق البحراني[الباحوري بر] وذلك أنّ هذا ليس يدلّ على أنّ القوّة قد ضعفت وانحلت

Here a matter is the opposite of this cause, and that is that which is in the critical sweat. For this does not indicate that the power is already weak and dissolved.

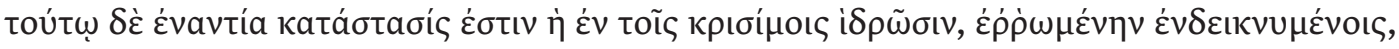

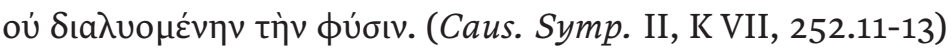

The opposite state to this is that in the critical sweats which indicate a strong rather than a dissolved nature. (trans. Johnston, 292-293)

\section{Text (79)}

Paris 67b22-23, Princeton 51a19-20

$$
\text { وذّلك لأنّ الرعدة ليس هي بتبديل [تبديل بر] حركة ابتدأها [تبدلها بر] قوّة واحدة كالنبض بل إنّما هي قتال ومجاهدة بين القوة }
$$

For the tremor is not brought about by a change of movement whose source is one power like the pulse, but it is a battle and struggle between the power and the weight of the body.

oú үà

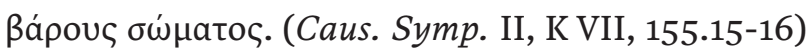

The alternation of movement is not brought about by one nature but there is a struggle between the capacity and the weight of the body. (trans. Johnston, 242)

\section{Text (80)}

Paris, 24b24-27, Princeton 14b23-24

$$
\text { أصلاً .... يقول إنّ الرياضة إن كانت يسيرة وكانت مع قلّتها ليست بالقوّيّة بل أضعف من قوّة بدن المرياض بها جداً لم يحدث عنها أعياء }
$$

He says that if the exercise is slight and together with being little it is also not vigorous, but much weaker than the power of the body of the one exercising it, no fatigue is produced from it at all.

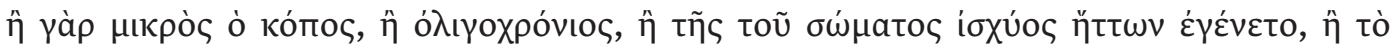

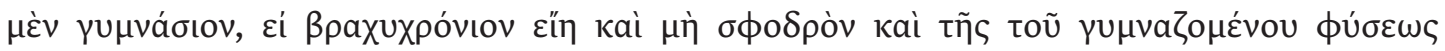

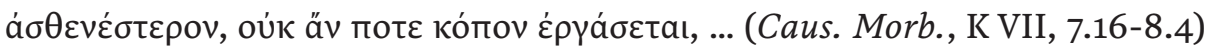


... or if the exercise [is - E. W.] of short duration, or not vigorous, or weaker than the natural constitution of the one exercising, it would not then bring about fatigue. (trans. Johnston, 162)

\section{PHYSIS $\rightarrow \check{G A W H A R}$}

Text (81)

Paris 60a9, Princeton 39b14

$$
\text { كما أنّ حاسّة المذاق إنّما تحسّ الجوهر الرطب }
$$

... as the sensation of taste perceives only the humid substance

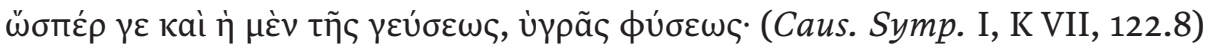

... just as that of taste is one of a moist nature .... (trans. Johnston, 223)

VI. PHYSIS $\rightarrow$ NO CORRESPONDING ARABIC TERM

VI. A. Omitting Galen's Demiurgic Nature

Text (82)

Paris, 18b6-7, Princeton 6b9-10

$$
\text { ... وملاسة الأعضاء أيضاً وخشونتها من الأشياء التي لمَ تُجعل بالطلاً ولا عبثاً }
$$

Also the smoothness of the parts and their roughness belongs to the things which are not made in vain and futile.

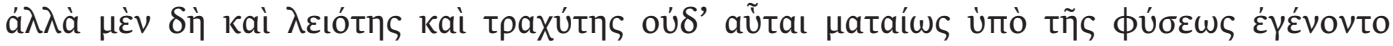

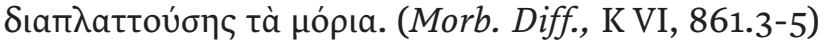

But, in fact, even smoothness and roughness are not themselves without purpose in the natural conformation of the parts. (trans. Johnston, 147)

Text (83)

Paris $28 \mathrm{~b} 21-24$, Princeton $18 \mathrm{a} 6-8$

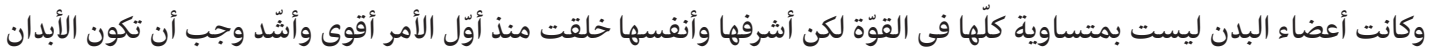

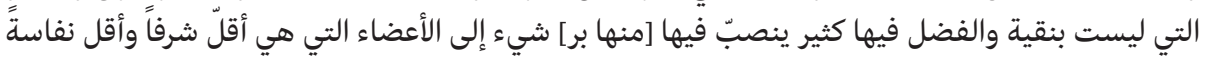


The parts of the body are not all equal in power, but the nobler and more precious ones of them have been created more powerful and intense from the beginning. It is necessary that in the bodies, which are not pure and in which there is much superfluity, something flows to the body parts which are of less nobility and preciousness.

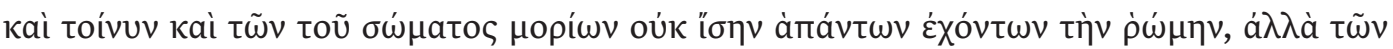

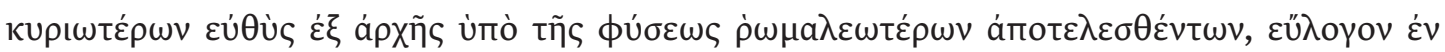

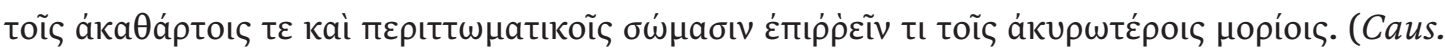
Morb., K VII, 24.10-14)

Moreover, since all parts of the body are not equal in strength, but the more important parts are from the very beginning made stronger by Nature, it is reasonable that in impure and superfluity-containing bodies something flows to the less important parts. (trans. Johnston, 171)

Text (84)

Paris 29a7-10, Princeton 18a16-19

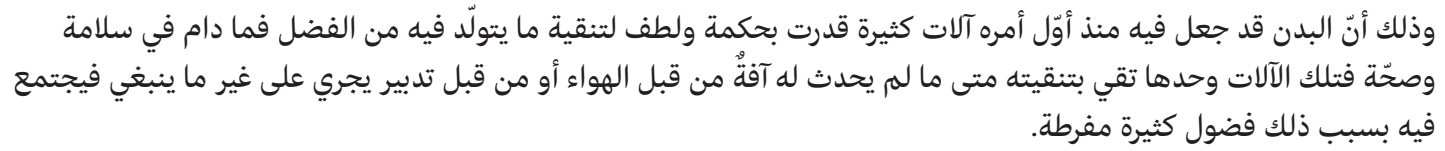

For, from the beginning, many organs have been made in the body which have been appointed by wisdom and kindness to clean the superfluity which is generated in (the body). So as long as it is in well-being and health, ${ }^{67}$ those organs alone preserve (it) through cleaning it, whenever no damage occurs to (the body) neither due to the air nor due to a conduct which is not as it should be. For due to that many excessive superfluities gather in (the body).

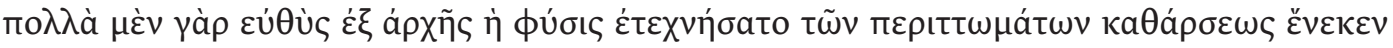

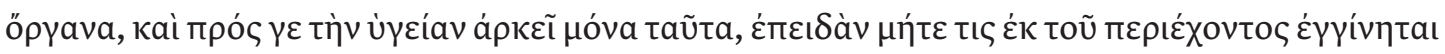

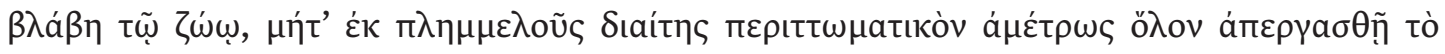

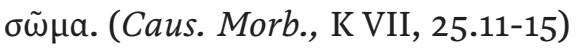

Right from the beginning, Nature has crafted many organs for the sake of the evacuation of superfluities, and these alone are sufficient for health whenever neither damage comes upon the animal from what surrounds, nor the whole body is made excessively superfluity-containing from a faulty way of life. (trans. Johnston, 171)

67 Health is rendered by the hendiadys salāma wa-sihḥa. 


\section{Text (85)}

Paris 61b23-26, Princeton 41a11-13

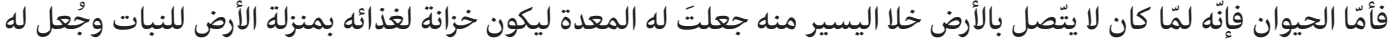

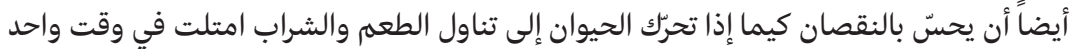

As for the animal, since it is not connected with the earth except for a minority of (animals), the stomach has been made for (the animal) so that it may be a treasure house for its nourishment like the earth for the plants. The fact that (the animal) perceives lack has also been made for (the animal) so that (the stomach) is refilled at one time, when the animal is moved to take food and drink.

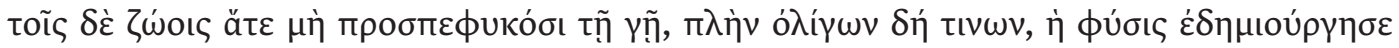

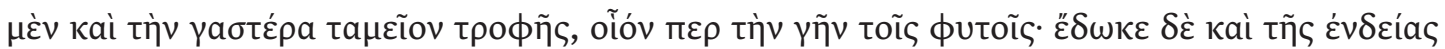

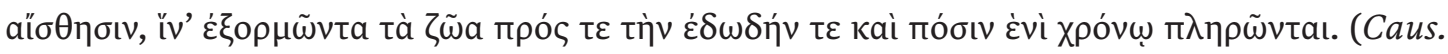
Symp. I, K VII, 129.15-130.2)

For animals, inasmuch as they are not made to grow by the earth, apart admittedly from a few instances, Nature has fashioned the stomach as a storehouse of nutriment, like the earth for plants. And it has given a perception of lack so that animals are stimulated to fill themselves with food and drink at one time. (trans. Johnston, 227)

\section{Text (86)}

Paris 64b22-23, Princeton 43a26-27

$$
\begin{aligned}
& \text { ولقد كان أولى [أولاً ب] وأقرب إلى الإقناع أن يقول إنّ النوم إنْما يكون عندما ترطب الرئة فإنّ الرئة لن تُخلَق [لن تخلق ب: لهم يخلق }
\end{aligned}
$$

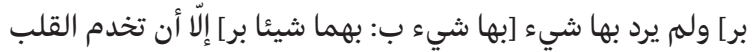

In truth, it is better suited and closer to conviction to say that sleep takes place when the lung becomes moist. For the lung is only created and meant for one thing, namely to serve the heart.

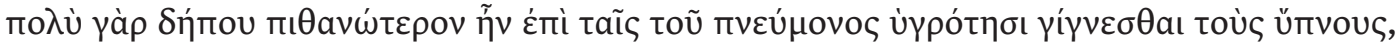

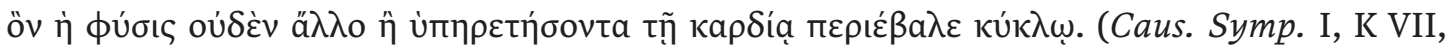
142.10-12)

For it is, of course, far more plausible for sleep to occur in moistenings of the lung, which Nature placed in a circle around the heart for no other reason than to serve it. (trans. Johnston, 233) 
Text (87)

Paris 52b28, Princeton 53b22-23

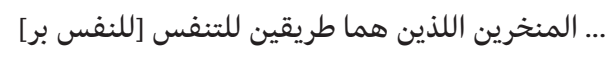

... the nostrils, which are two passages for respiration.

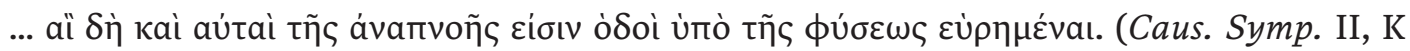
VII, 169.7-8)

[the nostrils - E. W.] which are themselves passages of respiration invented by Nature. (trans. Johnston, 248)

\section{Text (88)}

Paris 72a22-25, Princeton 65b14-15

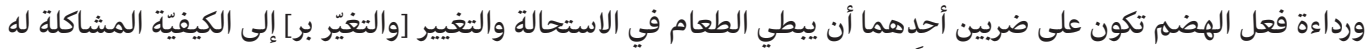

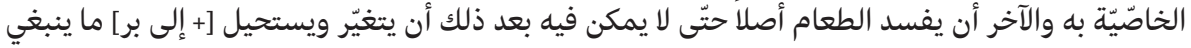

The defect of the digestive action is of two kinds: one of them is that the food is slowed down when changing and altering into the quality which is similar and suited ${ }^{68}$ to it; and the other is that the food corrupts completely so that with regard to it, it is afterwards not possible that it changes and alters as [or: into what] it should.

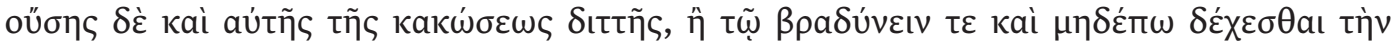

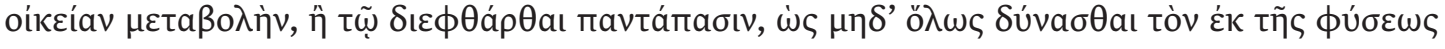

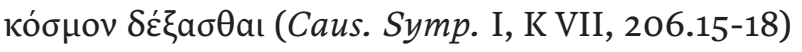

This malfunction is also twofold, either due to slowing and not yet taking on the proper change, or due to being completely ruined so it is altogether unable to take on the order of nature. (trans. Johnston, 269)

68 For hāasșī, see Ullmann, Wörterbuch, Suppl. 


\section{B. Omitting nature in various meanings}

Text (89)

Paris 21b14-16, Princeton 9a12-13

وأمّا النملة والسرطان فهما وسط فيما بين هذه وذاك أنّهما في أكثر الأمر يكونان مع قرحة وربّما كان كلّ واحد منهما بلا قرحة.

As for pustule and cancer, they are both a mean in between these, that is they two are many times with ulcer and sometimes each of them is without ulcer.

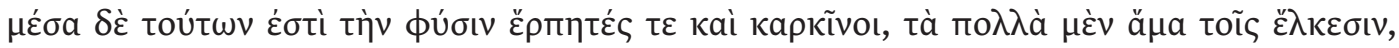

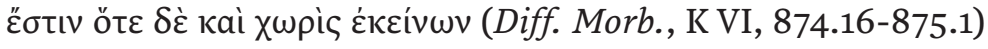

... whereas intermediate in nature between these are herpetes and cancers (karakinoi), many occurring accompanied by ulcers but sometimes also apart from them. (trans. Johnston, 153)

\section{Text (90)}

Paris, 36b6-7, Princeton 25b5-6

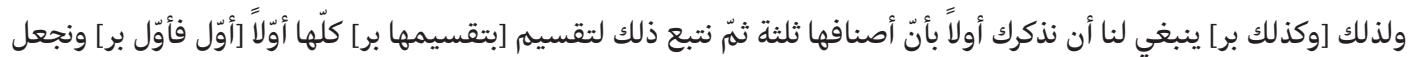

$$
\begin{aligned}
& \text { مبدأنا في ذلك [في ذلك ب: ـ برك] من مضار الفعل }
\end{aligned}
$$

Therefore it is necessary for us that we mention to you first that their sorts are three, then we let that be followed first by the division of all of them and then we make our beginning in that with the damage of the activity.

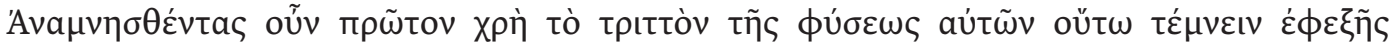

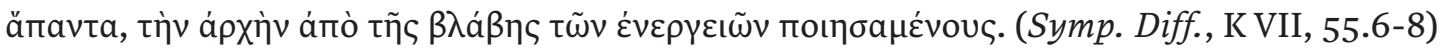

It is necessary, then, having first called to mind the threefold nature of these [symptoms], to divide them all in this way in turn, making a start from the damage of functions. (trans. Johnston, 188)

\section{Text (91)}

Paris 43a9, Princeton $30 b 27$

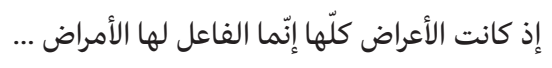

Since the agent of all symptoms are the diseases ...

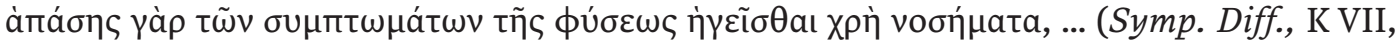
81.7-8)

For diseases must precede every kind [physis - E. W.] of symptom, ... (trans. Johnston, 201) 


\section{Text (92)}

Paris, 47a27-28, Princeton $35 a 6$

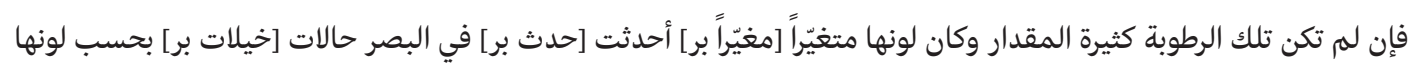

If this humour is not much in quantity and its colour changed, conditions occur according to its colour in vision.

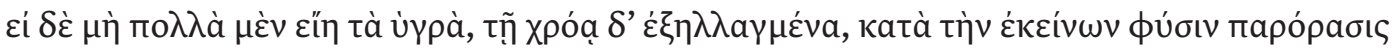
ý́rvetaı. (Caus. Symp. I, K VII, 99.9)

If the fluids are not great in amount but are changed in colour, a false vision involving the nature of those things occurs. (trans. Johnston, 212)

\section{Text (93)}

Paris 68a22-23, Princeton $39 a 10$

$$
\text { واللطيف الأجزاء أبداً أقوى من الغليظ الأجزاء }
$$

The fine with regard to its parts is always more powerful than the thick with regard to its parts.

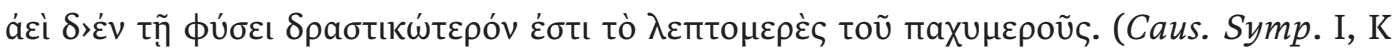
VII, 119.11)

Invariably in Nature what is composed of fine particles is more efficacious than what is composed of thick particles. (trans. Johnston, 222)

\section{Text (94)}

Paris 64a17-18, Princeton 43a2

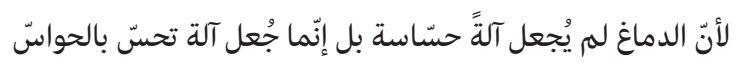

For the brain is not made as a sensible organ, but is made as an organ which perceives sensations.

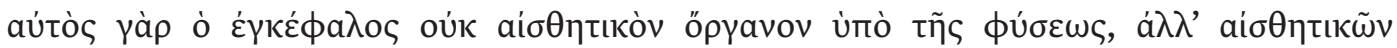

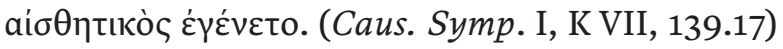

For the brain itself is not by nature a perceiving organ, but the perceiver of what is perceived. (trans. Johnston, 232) 


\section{ADDING NATURE IN ARABIC (some examples)}

Text (95) - ousia $\rightarrow$ țabía

Paris 42b6-9, Princeton 3ob3-4

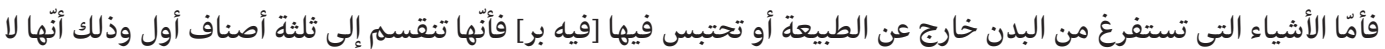

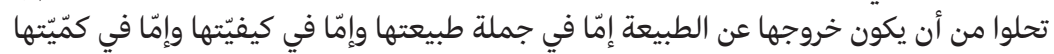

As for the things which are expelled from the body contrary to nature or retained in it, they are divided into three primary kinds, that is that they are not free from their being contrary to nature either in the entirety of their nature or in their quality or in their quantity.

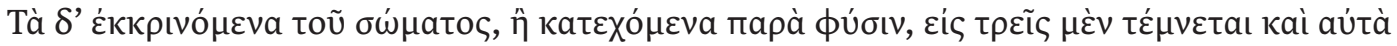

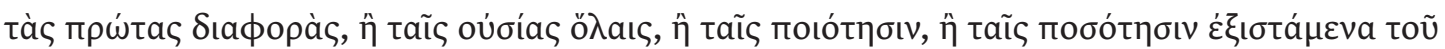

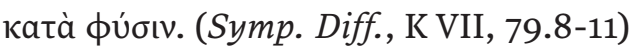

Things expelled from the body, or retained contrary to nature, are themselves divided into three primary differentiae, according to whether they depart from what accords with nature in whole substances, in qualities or in quantities. (trans. Johnston, 200)

Text (96) - zōon $\rightarrow$ țabīia

Paris 43a11-21, Princeton 31a2-9

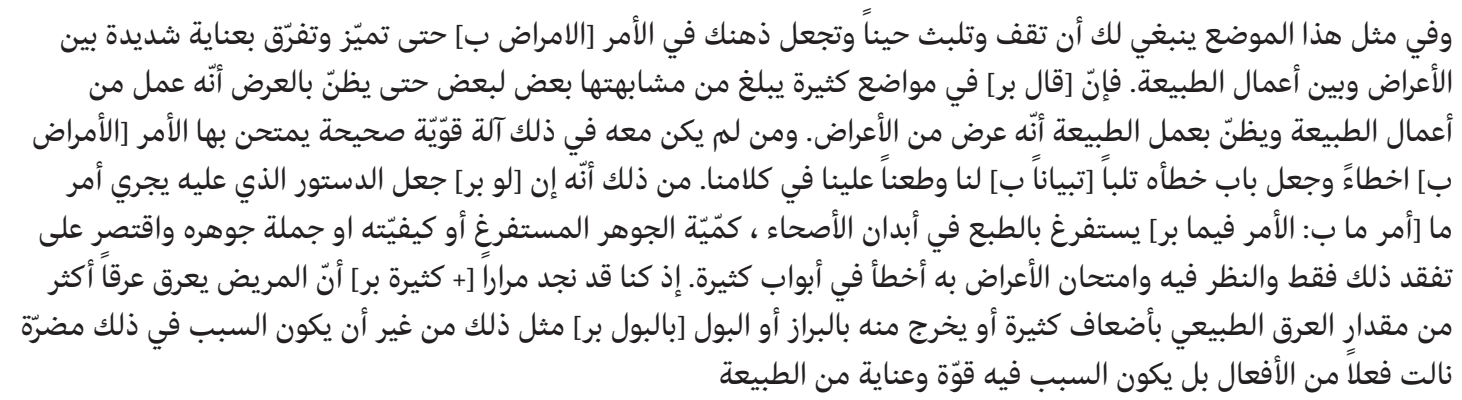

With regard to something like this topic, it is necessary for you that you stand still and linger for some time and make up your mind about the matter, so that you distinguish and divide with intense care between the symptoms and between the works ${ }^{69}$ of nature. For in many places some attain a high degree of resemblance to others, so that one may suspect the symptom to be one of the works of nature; and one may suspect the work of nature to be one of the symptoms. He, who, with regard to that, does not have a powerful and sound instrument with him, will test the matter faultily by them. He makes the subject of his error a disadvantage for and a criticism of us with regard to our discussion. Therefrom, if he makes the quantity of the emptied substance or its quality or the entirety of its substance the model, according to which the matter of naturally emptying happens in the bodies of the healthy,

69 The consistent use of two different Arabic terms for ergon ( $\mathrm{amal}$ ) and energeia $(\mathrm{f} i \mathrm{l}$ ) here is remarkable as they are normally both translated with the same term $f i$. 
and if he restricts himself to the examination of only that, to the consideration of it and to the testing of the symptoms through it, he will err in many subjects. For we often used to find that the sick sweated many times more than the natural amount of sweat or excreted excrement or urine like that without the cause for that being a damage which got hold of one of the activities, rather the cause for it being the power and care of nature.

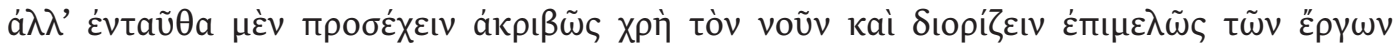

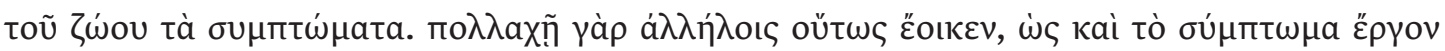

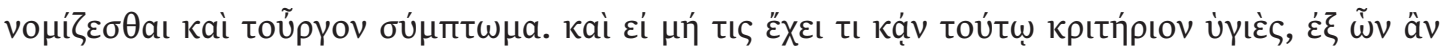

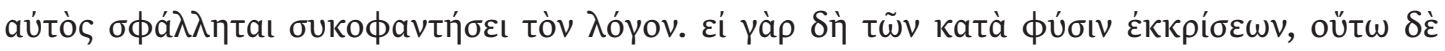

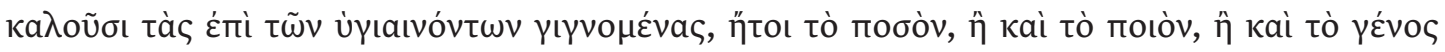

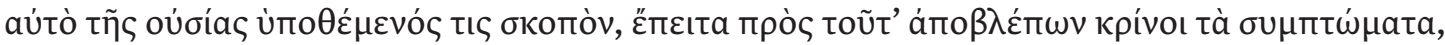

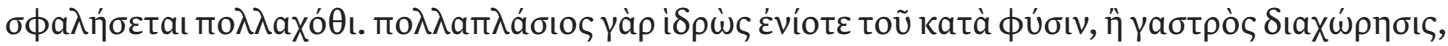

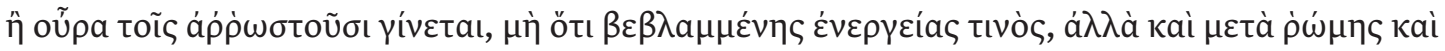

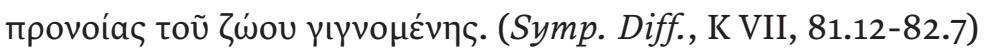

But here we ought to pay close attention to, and distinguish carefully, symptoms from the actions of the animal. For frequently one may seem like the other, so the symptom may be thought to be an action or the action a symptom. And if someone does not have sound judgement in this too, from those things he should be mistaken about, he would criticize the argument in a pettifogging way. For if of the expulsions that accord with nature, as they call those occurring in the case of the healthy, someone proposes as an object of attention the quantity, quality or actual class of the substance, and then paying attention to this assesses the symptoms, in many instances he will be wrong. For sometimes it happens that the sweat is much more than accords with nature, or the excretion of the stomach, or the urine of those who are unwell, although it is not that some function is damaged, but that this occurs along with the bodily strength and care of the animal. (trans. Johnson, 201, slightly changed)

Text (97) - òmos $\rightarrow$ tada u l-țabìatu l-ahlāța nìatan

Paris 73a26-27, Princeton 66b9

$$
\text { وأمّا في العروق فانحسام الفعل يكون عندما تدع الطبيعةٌ الأخلاط نيئة لا نضج لها أصلاً }
$$

As for in the blood vessels, there is the cutting of the activity when nature leaves the humours raw and not having ripeness.

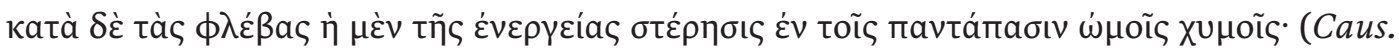
Symp. III, K VII, 210.16-17)

Regarding the veins, there is privation of function in the altogether undigested humours, ... (trans. Johnston, 271) 
Text (98) dynamis $\rightarrow$ tabìa

Paris 78b1-3; Princeton 71a8-10

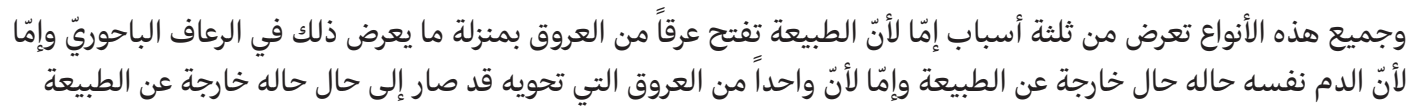

All these kinds happen from three causes, either because nature opens one of the blood vessels like that happening in the anomalous nosebleed, or because the condition of the blood itself is a condition outside nature, or because one of the blood vessels, which contain it, arrives at a condition, in which its condition is outside nature.

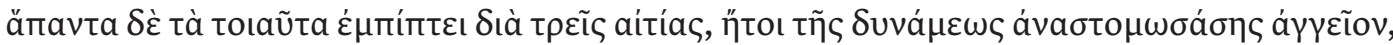

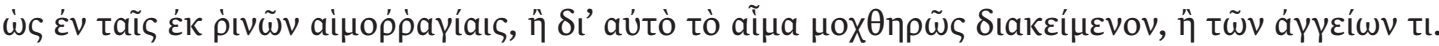
(Caus. Symp. III, K VII 233.7-10)

All such things happen from three causes: either when the capacity opens up a vessel as in haemorrhages from the nose, or by the blood itself being adversely affected, or one of the vessels [being adversely affected]. (trans. Johnston, 283)

\title{
Acknowledgements
}

The research presented in this article started in the framework of the project Philosophical and Theological Elements in Byzantine and Arabic Medical Traditions (156439) funded by the Swiss National Science Foundation (SNF/FNS) and directed by Christophe Erismann at the University of Lausanne. It was continued in the framework of the bilateral project Galen in Arabic - More than a Translation (I 3895) funded by the French National Research Agency (ANR) and the Austrian Science Fund (FWF) and directed by Pauline Koetschet at the IFPO, Beirut and Elvira Wakelnig at the University of Vienna. The research profited greatly from the cooperation with the research project PhASIF (DIM, Île-de-France) directed by Maroun Aouad, thanks to which it was possible to obtain access to the Manissa and the Tehran manuscripts. I would like to express my heartfelt gratitude to Christophe Erismann for endless discussions on this research, his remarks and ideas, and to Jawdath Jabbour for his immensely helpful comments.

\author{
Abbreviations \\ $\mathrm{CMG}=$ Corpus Medicorum Graecorum \\ GAS = Geschichte des arabischen Schrifttums \\ $\mathrm{K}=$ Kühn's edition of Claudii Galeni opera omnia \\ Caus. Morb. = De Causis Morborum \\ Morb. Diff. = De Morborum Differentiis \\ Caus. Symp. = De Symptomatum Causis \\ Symp. Diff. = De Symptomatum Differentiis \\ TLG $=$ Thesaurus Linguae Graecae
}




\section{References}

Agnellus of Ravenna, Lectures on Galen's De Sectis. Latin Text and Translation by Seminar Classics 609, State University of New York at Buffalo (Buffalo, 1981).

Bernand, Marie, La critique de la notion de nature (țab) par le Kalām, Studia Islamica 51 (1980) 59-105.

Cooper, Glen M., Ḥunayn ibn Isḥāq's Galen translations and Greco-Arabic philology: Some observations from the Crises (De crisibus) and the Critical Days (De diebus decretoriis), Oriens 44 (2016) 1-43.

Doctrina Patrum De incarnatione verbi: Ein griechisches Florilegium aus der Wende des 7. und 8. Jahrhunderts, ed. Franz Diekamp (Second edition, revised by Avangelos Chrysos) (Münster, 1981).

Gacek, Adam, Arabic Manuscripts: A Vademecum for Reader. Handbook of Oriental Studies, Section 1: The Near and Middle East 98 (Leiden, 2009).

Galen, Claudii Galeni opera omnia, ed. Carl Gottlob Kühn, 20 vols (Leipzig, 1821-1833; repr. Hildesheim, 1965).

Galen, On Diseases and Symptoms, trans. Ian Johnston (Cambridge, 2006).

Galen, On Food and Diet, trans. Mark Grant (London, 2000).

Galen, On Hippocrates' "Nature of Man«, ed. Ioannes Mewaldt, CMG V 9,1 (Leipzig, 1914) 1-113.

Galen, On Medical Names, ed. and German trans. Max Meyerhof and Joseph Schacht, $\mathrm{Ga}$ len: Über die Medizinischen Namen, Arabisch und Deutsch. Abhandlungen der Preussischen Akademie der Wissenschaften 3 (Berlin, 1931).

Galen, On the Natural Faculties, ed. and trans. Arthur John Brock (London, 1916).

Galen, On the Usefulness of the Parts of the Body, trans. M. T. May (Ithaca, NY, 1968).

Galen, Über die Verschiedenheit der Symptome, ed. and trans. Beate Gundert, CMG V 5, 1 (Berlin, 2009).

Gannagé, Emma, Philopon (Jean -): Tradition Arabe, in: Richard Goulet (ed.), Dictionnaire des Philosophes Antiques: Va de Paccius à Plotin (Paris, 2012) 503-563.

Garofalo, Ivan, La nature d'Hippocrate chez les Alexandrins, in: Antoine Thivel (ed.), Le normal et le pathologique dans la Collection hippocratique 2 (Nice, 2002) 753-765.

[Ğawämi] The Alexandrian Compendium of Galen's Work: Jawāmi al-Iskandaräniyyīn, trans. Hunayn ibn Ishāa, ed. Fuat Sezgin, Publications of the Institute for the History of Arabic-Islamic Science, Series C, Facsimile Editions Volume 68, 1-3, 3 vols (Frankfurt/Main, 2001-2004).

Genequand, Charles, Quelques aspects de l'idée de nature, d'Aristote à al-Ghazâlî, Revue de théologie et de philosophie 116/2 (1984) 105-129.

Gutas, Dimitri, Aspects of literary form and genre in Arabic logical works, in: Charles Burnett (ed.), Glosses and Commentaries on Aristotelian Logical Texts: The Syriac, Arabic and Medieval Traditions (London, 1993) 29-76.

Gutas, Dimitri, Greek Thought, Arabic Culture: The Graeco-Arabic Translation Movement in Baghdad and Early 'Abbäsid Society (2nd-4th/8th-1oth centuries) (London, 1998).

Hippocrates, al-Fusūl al-ibuqrätìya: The Aphorisms of Hippocrates. Translated into Arabic by Hosain ben Ishak, Physician to the Caliph Motawukkul, ed. John Tytler (Calcutta, 1832).

Ḥunayn ibn Ishāā, Risāla, ed. and trans. Gotthelf Bergsträsser, Hunain ibn Ishāa über die syrischen und arabischen Galen-Übersetzungen (Leipzig, 1925). 
Ḥunayn ibn Ishāà, Risāla, ed. and trans. Fabian Käs, Eine neue Handschrift von Ḥunain ibn Isḥāqs Galenbiographie, Zeitschrift für Geschichte der arabisch-islamischen Wissenschaften 19 (2010-2011) 135-193.

Ḥunayn ibn Isḥāq, Risāla, ed. and trans. John C. Lamoreaux, Hunayn ibn Isḥāq on His Galen Translations (Provo, Utah, 2016).

Ibn Ğulğul, Ṭabaqāt al-ațibbā' 'wa-l-h̆ukamā', ed. Fu'ād Sayyid (Cairo, 1995).

Johannes Alexandrinus, Commentaria in librum de sectis Galeni, ed. C. D. Pritchet (Leiden, 1982).

Johannes Alexandrinus, Commentaria in sextum librum Hippocratis Epidemiarum (Leiden, 1975).

John of Damascus, Institutio Elementaris: Capita Philosophica (Dialectica), ed. Bonifatius Kotter, Die Schriften des Johannes von Damaskos I (Berlin, 1969).

Jouanna, Jacques, La Notion de Nature chez Galien, in: Jonathan Barnes and Jacques Jouanna (ed.), Galien et la Philosophie. Entretiens sur l'Antiquité classique 49 (Genève, 2003) 229262; English translation: Jouanna, Jacques, Galen's concept of nature, in: Philip van der Eijk (ed.) and Jacques Jouanna, Greek Medicine from Hippocrates to Galen: Selected Papers, translated from French by Neil Allies. Studies in Ancient Medicine 40 (Leiden, 2012) 287-311.

Krāwus [Kraus], P. [Paul], Kitāb al-ahlāq li-Ǧālīnūs, Bulletin of the Faculty of Arts of the University of Egypt 5 (1937) 1-51.

Kovačić, Franjo, Der Begriff der Physis bei Galen vor dem Hintergrund seiner Vorgänger (Stuttgart, 2001).

Mach, Rudolf and Eric L. Ormsby, Handlist of Arabic Manuscripts (New Series) in the Princeton University Library (Princeton, 1987).

Maclean, Arthur John, A Dictionary of the Dialects of Vernacular Syriac as Spoken by the Eastern Syrians of Kurdistan, North-West Persia, and the Plain of Moșul (Oxford, 1901).

Moraux, Paul, Ein unedierter Kurzkommentar zu Porphyrios' Isagoge, Zeitschrift für Papyrologie und Epigraphik 35 (1979) 55-98.

Al-Kindī, Risāla fì Ḥudūd al-ašyā' wa-rusūmihāa, in: Rasā'il al-Kindì al-falsafìya, ed. Muhạmmad 'Abd al-Hādī Abū Rīda (Cairo, 1950-1953) I, 165-179.

Overwien, Oliver, The art of the translator, or: How did Hunayn ibn 'Ishāq and his school translate? in: Peter E. Pormann (ed.), Epidemics in Context: Greek Commentaries on Hippocrates in the Arabic Tradition. Scientia Graeco-Arabica 8 (Berlin, 2012) 151-169.

Overwien, Oliver, Medizinische Lehrwerke aus dem spätantiken Alexandria: Die Tabulae Vindobonenses und Summaria Alexandrinorum zu Galens De sectis. Scientia Graeco-Arabica 24 (Berlin, 2019).

Overwien, Oliver, Die orientalische Überlieferung, in: Galen, Über die Verschiedenheit der Symptome, ed. and trans. Beate Gundert, CMG V 5, 1 (Berlin, 2009) 103-148.

Pormann, Peter E., The Alexandrian Summary (Jawämi) of Galen's On the Sects of Beginners: Commentary of abridgment?, in: Peter Adamson, Han Baltussen and Martin W. F. Stone (eds.), Philosophy, Science and Exegesis in Greek, Arabic, and Latin Commentaries. Bulletin of the Institute of Classical Studies Supplement 83/2 (London, 2004) 11-33.

Ritter, Helmut and Richard Walzer, Arabische Übersetzungen griechischer Ärzte in Stambuler Bibliotheken, Sitzungsberichte der preussischen Akademie der Wissenschaften, Phil.-hist. Klasse 26 (1934) 801-846.

Saliba, George, Islamic Science and the Making of the European Renaissance (Massachusetts, 2007). 
Savage-Smith, Emilie, Galen's lost ophthalmology and the Summaria Alexandrinorum, in: Vivian Nutton (ed.), The Unknown Galen. Bulletin of the Institute of Classical Studies Supplement 77 (London, 2002) 121-138.

Schiefsky, Mark J., Galen's teleology and functional explanation, Oxford Studies in Ancient Philosophy 33 (2007) 369-400.

Sezgin, Fuat, GAS III: Medizin-Pharmazie. Zoologie-Tierheilkunde bis ca. 430 H. (Leiden, 1970). Le Baron de Slane, Catalogue des manuscrits arabes (Paris, 1883-1895).

Stephanus the Philosopher and Physician, Commentary on Galen's Therapeutics to Glaucon, ed. Keith Dickson, Studies in Ancient Medicine 19 (Leiden, 1998).

Theodore of Raïthu, Praeparatio sive De incarnatione, in: Franz Diekamp (ed.), Analecta patristica: Texte und Abhandlungen zur griechischen Patristik. Orientalia Christiana analecta 117 (Rome, 1938) 173-222.

Ullmann, Manfred, Wörterbuch zu den griechisch-arabischen Übersetzungen des 9. Jahrhunderts, Supplement, 2 vols (Wiesbaden, 2006-2007).

Vagelpohl, Uwe, The user-friendly Galen: Hunayn ibn Ishāq and the adaptation of Greek medicine for a new audience, in: Petros Bouras-Vallianatos and Sophia Xenophontos (eds.), Greek Medical Literature and its Readers: From Hippocrates to Islam and Byzantium (London, 2018) 113-130.

Vajda, Georges, Notices des manuscrits arabes 2760 à 3184: Notices manuscrits arabe 2845-2874 (handwritten and typed notes) (1940-1969). Accessed on 19th June 2020: https://gallica. bnf.fr/ark:/12148/btv1b8470424s.

Walbridge, John, The Alexandrian Epitomes of Galen. Volume 1: On the Medical Sects for Beginners. The Small Art of Medicine: On the Elements According to the Opinion of Hippocrates (Provo, Utah, 2014).

Wakelnig, Elvira, Medical knowledge as proof of the Creator's wisdom and the Arabic reception of Galen's On the Usefulness of the Parts, in: Petros Bouras-Vallianatos and Sophia Xenophontos (eds.), Greek Medical Literature and its Readers: From Hippocrates to Islam and Byzantium (London, 2018) 131-149.

Watt, John W., Why did Hunayn, the master translator into Arabic, make translations into Syriac? On the purpose of the Syriac translations of Hunayn and his circle, in: John W. Watt (ed.), The Aristotelian Tradition in Syriac (London, 2019) 123-140. 